\title{
Tratamiento de primera línea para pacientes con mieloma múltiple no elegibles para trasplante autólogo de células progenitoras: revisión sistemática y meta-análisis (estudio del Hemo-ONCOLGroup)
}

First line therapy for patients with newly diagnosed multiple myeloma ineligible for autologous stem cell transplantation: a systematic review and meta-analysis (Hemo-ONCOLGroup study)

\footnotetext{
- Myriam Rodríguez',2, Juan Felipe Combariza 2,3, Claudia Patricia Casas 2,4, Ludovic Reveiz 2,5, Jefferson Buendía ${ }^{5}$ Arturo Martí-Carvajal ${ }^{6}$, Henry Becerra ${ }^{7}$, Andrés Acevedo', Andrés Felipe Cardona ${ }^{2,7}$

'Hematology and Bone Marrow Therapy Department, Fundación Santa Fe de Bogotá (Bogotá, Colombia).

'Hematology and Bone Marrow Therapy Department, Fundacion Santa Fe de Bogotá (Bogotá, Colombia).

Associate researcher, Colombian Group for the Clinical and Translational Research of Cancer (ONCOLGroup), hae

${ }^{4}$ Hematology Department, Hospital de San José (Bogotá, Colombia).

5Clinical Research Institute, Clinical Epidemiology and Health Technology Assessment Unit, National University of Colombia (Bogotá, Colombia).

6 Iberoamerican Cochrane Network (Valencia, Venezuela).

${ }^{7}$ Clinical and Translational Oncology Group, Fundación Santa Fe de Bogotá (Bogotá, Colombia)
}

\section{Resumen}

Antecedentes: Los pacientes con mieloma múltiple (MM) que no son elegibles para Trasplante de Médula Ósea han sido tratados con melfalán $(\mathrm{M})$ más prednisona $(\mathrm{P})$; sin embargo, el estándar de tratamiento ha cambiado a MP mas talidomida (T) debido a un beneficio en supervivencia. Bortezomib (B) y lenalidomida también han surgido como tratamientos efectivos. Métodos: Se identificaron los ensayos clínicos aleatorizados y controlados (RCT) obtenidos en la Librería Cochrane, PUBMED, LILACS, EMBASE y Scirus. Sólo se consideraron los estudios que compararon melfalán-prednisolona (MP) con cualquier otro régimen.

Resultados: Se analizaron 22 RCTs, de 2.159 referencias. MP vs. M mas dexametasona (MD): 3 RCT. No hubo diferencias respecto de la supervivencia global (SG), la tasa de respuesta completa (TRC) y la toxicidad hematológica. MD fue superior en respuesta parcial (RR 1.54;1.32-1.80) y toxicidad no hematológica RR 2.15;1.36-3.41. MP vs. regímenes basados en talidomida: 4 RCT. Se encontraron diferencias a favor de la talidomida respecto de la TRC RR 3.44;1.86-6.39 y respuesta parcial (RP) RR 1.67;1.28-2.17. La supervivencia libre de progresión (SLP) fue superior con talidomida $(p=0.02)$. MP vs. regímenes basados en bortezomib: 1 RCT. Se encontraron diferencias significativas a favor de bortezomib en SG HR 0.61;0.42-0.89, tiempo a la progresión HR 0.48;0.41-0.56, TRC RR 8.35;4.68-14.89 y RP RR 1.30;1.06-1.59. MP vs. quimioterapia sin M: 3 RCT. Los esquemas con bendamustina lograron una mayor respuesta completa RR 2.55;1.22-5.30. MP vs. Otros: 13 RCT. No se encontraron diferencias en la RP, SG ni en los efectos adversos.

Conclusiones: Los pacientes sintomáticos con MM no elegibles para trasplante de médula ósea deben recibir como primera línea una combinación de MP con bortezomib o talidomida. Se necesitan más estudios que permitan determinar el beneficio terapéutico basado en el fenotipo y la citogenética.

Palabras clave: mieloma múltiple, quimioterapia, ensayo clínico controlado, revisión sistemática, meta-análisis.

Received: December 25, 2011. Approved: February 21, 2012. 


\begin{abstract}
Background: Patients with multiple myeloma (MM) not eligible for SCT have been treated with melphalan (M) plus prednisone (P); however, the standard of care has shifted to MP plus thalidomide (T) due to a greater survival benefit. Bortezomib (B) and lenalidomide have also emerged as effective agents.

Methods: Randomized clinical trials (RCT) were identified from the Cochrane Library, PubMed, Lilacs, Embase and Scirus, that compare MP to any other regimen.

Results: Twenty-two trials were included from 2159 potentially eligible references. MP vs. M plus dexamethasone (MD): (3 $R C T)$ MD was superior in partial response (PR) rate and non-hematological toxicity. MP vs. T-based regimens: (4 RCT) significant differences favoring T-based regimens in CR rate, PR rate, and progression-free survival (PFS). MP vs. B based regimens: (1 RCT) Significant differences in OS, TTP, CR rate and PR rate favored B-based regimens according to the EBMT criteria. MP vs. chemotherapy regimens without $\mathrm{M}$ : (3 RCT) A significantly higher number of patients treated with BP achieved a CR. TTP was also significantly longer in BP-treated patients $(p<0.02)$. MP vs. other polychemotherapy regimens: $(13 \mathrm{RCT})$ No significant differences in PR, OS, hemathological or other type of toxicity were observed between MP and the other chemotherapy regimens.

Conclusions: Symptomatic MM patients ineligible for SCT should receive as first-line treatment a combination of MP plus B or T; these regimens are associated with improved outcome but greater toxicity compared to MP alone. More homogeneous clinical trials using a cytogenetic risk approach are required.
\end{abstract}

Key words: multiple myeloma, chemotherapy, randomized controlled trial, systematic review, meta-analysis.

\section{Introduction}

Multiple myeloma (MM) is a clonal malignancy characterized by proliferation of abnormal plasma cells that impair hematopoiesis, activate bone resorption, and secrete a monoclonal paraprotein in serum and urine'. MM accounts for about $1 \%$ of human neoplasms, almost $2 \%$ of cancer-related deaths, and $12-15 \%$ of hematological malignancies ${ }^{2}$. MM patients with symptomatic disease are usually considered candidates for chemotherapy-based treatment ${ }^{3}$ : those who are eligible for high-dose therapy followed by stem cell transplantation (SCT), and those who are ineligible for $\mathrm{SCT}^{4}$. Criteria for deciding on eligibility for SCT generally include age, performance status (PS), and co-morbid conditions ${ }^{5}$. There is some variability in these parameters and how they are applied, since studies examining SCT have been carried out with heterogeneous criteria. For example, initial studies tended to include patients younger than 65 years of age, while more recent trials suggest that SCT is safe in a selected group of patients over $70^{6}$. On the other hand, since patients with poor-risk chromosomal features have a short progression free survival (PFS) after SCT, even younger patients with these alterations may not be candidates for transplantation?

Since the 1960s, the standard of care for patients ineligible for SCT has been melphalan plus prednisone $(\mathrm{MP})^{8}$; this regimen has the advantages of an oral, outpatient administration schedule and is generally welltolerated. Moreover, a classic study demonstrated that while combination chemotherapy tended to induce a more rapid response, and a higher overall response rate (ORR), these differences did not translate into a survival advantage compared to MP9 . Though MP has been the standard of care for patients with newly diagnosed MM ineligible for SCT, other options include dexamethasone (D) alone and melphalan plus dexamethasone (MD) ${ }^{4}$. The Intergroupe Francophone du Myélome (IFM) randomized patients who were 65 to 75 years of age to receive $M P, M D, D$ alone, or $D$ plus interferon ${ }^{10}$. While none of these regimens induced a significant number of complete responses, patients receiving MD had a $70 \%$ ORR, defined as achieving at least a partial response (PR), which was significantly higher than that seen with any of the other three regimens; however, MD was also associated with a greater risk of toxicity, especially severe infections. Furthermore, the higher response rate with MD did not translate into either a significantly better median PFS or overall survival (OS ${ }^{10}$.

Thalidomide has also been added to MP (MPT) ${ }^{11,12}$. Recently, Palumbo et al found that newly diagnosed MM patients treated with MPT had a significantly higher ORR and longer PFS, as well as a trend towards longer OS, than those treated with $\mathrm{MP}^{13}$. In an updated analysis after a median follow-up of 38 months, median PFS was 21.8 months for MPT and 14.5 months for MP $(p=0.004)$, median OS was 45 months for MPT and 47.6 months for MP $(p=0.79)$. Moreover, PFS was longer with MPT regardless of age, serum concentrations of B2-microglobulin, or high International Staging System (ISS) ${ }^{14}$. However, MPT failed to show any significant benefit in OS, which 
could be due to the administration of new agents, such as bortezomib, after relapse.

Proteasome inhibition with bortezomib is a rational approach for the treatment of MM, and when combined with other drugs, bortezomib has been shown to enhance chemosensitivity and overcome chemoresistance in both preclinical and clinical studies ${ }^{15-17}$. The Spanish Multiple Myeloma Group (SMMG) carried out a large phase III trial comparing bortezomib plus MP (BMP) to MP. PFS was 24 months for patients receiving BMP, compared to 16.6 months for those receiving MP $(p<0.001)$. In the BMP arm, $71 \%$ of patients attained a PR and $30 \%$ attained a CR, compared to $35 \%$ and $4 \%$, respectively, in the MP arm $(p<0.001)$. The hazard ratio (HR) for OS was 0.61 for the BMP arm $(p=0.008)$. Adverse events were consistent with established toxicity profiles for the BMP and MP regimens ${ }^{18}$.

In this systematic review and meta-analysis, we assess the evidence from randomized clinical trials comparing MP to some other regimen in order to determine the efficacy and toxicity of different systemic treatments for newly diagnosed MM patients ineligible for SCT.

\section{Methods}

\section{Literature search}

Relevant randomized controlled trials (RCTs) were identified from the Cochrane Central Register of Controlled Trials (The Cochrane Library 2008, Issue 3), PubMed (1966 to April 2009), Lilacs (1982 to December 2008), Embase (1980 to December 2008) and Scirus (December 2008). A search strategy to locate studies on newly diagnosed MM patients ineligible for SCT was structured and adapted according to each electronic database (Appendix A). Ongoing trials were searched using the following web sites: the International Clinical Trials Registry Platform (ICTRP) search portal (<http:// www.who.int/trialsearch/Default.aspx >); the metaRegister of Controlled Trials (<www.controlled-trials. com>); and <http://clinicaltrials.gov/>. Eligible RCTs were included regardless of the language of publication. We also scanned bibliographies of relevant studies for possible references to additional RCTs and searched the abstracts from the annual meetings of the American Society of Clinical Oncology (ASCO), the American Society of Hematology (ASH) and the European Society of Medical Oncology (ESMO) from 1980 onwards.
Pharmaceutical firms and authors were also contacted when deemed necessary.

\section{Study selection}

Only RCTs comparing MP versus any other regimen for newly diagnosed MM patients ineligible for SCT were considered in the systematic review. We considered all doses and regimens of treatments whether as single agents or in combination therapy. Quasi-randomized and non-randomized controlled studies were excluded. Trials were included based on the independent decisions of at least two reviewers, and any disagreements were resolved by discussion, with referral to a third reviewer if necessary.

\section{Data extraction}

At least two reviewers independently extracted the relevant data using a pre-designed data extraction form, and any disagreement was resolved by consensus among all reviewers. Extracted data included the year of publication, patient population, number of patients (by intent-to-treat [ITT] analysis), sample size, sociodemographic details, treatment details (drug, dose, duration), clinical outcomes and main adverse events.

\section{Definitions and outcomes}

The primary outcomes were ORR, PFS and OS. In addition, we also considered TTP and the rate of adverse events as secondary outcomes -following the National Cancer Institute Common Terminology Criteria for Adverse Events (CTCAE) version 3.0-; no further searches for other types of studies were attempted to identify adverse events ${ }^{19,20}$.

\section{Risk of bias assessment}

A risk of bias evaluation of each RCT was done to include details of randomization, allocation concealment, blinded assessment, incomplete outcome data, selective outcome reporting and other issues, in accordance with the guidelines contained in the Cochrane Collaboration handbook ${ }^{21}$. The tool for assessing risk of bias in each RCT comprises a description and a judgment for each entry in a risk-of-bias table. The judgment for each entry involves answering a question, with "Yes" indicating low risk of bias, "No" indicating high risk of bias, and "Unclear" indicating either lack of information or uncertainty over the potential for bias. A study should 
be considered has having a low risk of bias if all key domains were judged as "Yes" and with unclear risk if the reviewers answered "Unclear" for one or more key domains ${ }^{21}$.

Additional information included inclusion and exclusion criteria, sample size calculation, and baseline comparability of age, gender, relevant clinical characteristics, diagnosis and duration of complaint.

\section{Description of studies}

Of 2159 RCTs screened, 106 assessed the efficacy in terms of OS and PFS and the toxicity of systemic treatment of newly diagnosed MM patients ineligible for SCT (figure 1). Of these, 25 RCTs meeting the inclusion criteria ${ }^{13,14,18,22-44}$, two ${ }^{14,43}$ were an update of other studies $^{13,18}$ and two were published only as abstracts ${ }^{41,42}$. Eighty one references were excluded either because they were non-randomized trials or because they did not compare MP versus another regimen ${ }^{45-129}$ (figure 1). The main characteristics of the 25 included studies are detailed in Annex 1.

Only two studies were not open ${ }^{42,44}$ and three had a low risk of bias ${ }^{13,34,39}$. Overall, 19 RCTs were judged to have an unclear risk of bias, mainly because the description of the method used to generate the allocation sequence and/or to conceal the allocation was unclear (Annex 2). The majority of RCTs did not calculate the sample size, which was a potential source of imprecision.

\section{Statistical analysis}

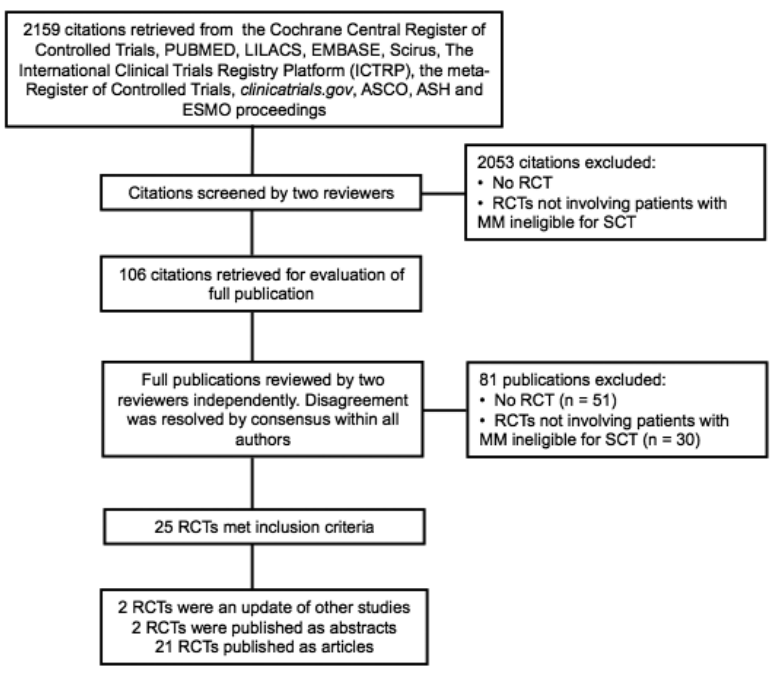

Figure 1. References screened and selected for the systematic review.
To estimate differences between treatments, we pooled the results of RCTs comparing similar treatments and controls and then calculated a weighted treatment effect across the studies. Results were expressed as risk ratios (RR) with $95 \%$ confidence intervals $(\mathrm{Cl})$ for dichotomous outcomes and weighted mean differences (WMD) with 95\% Cls for continuous outcomes. The generic inverse variance by logHR and SE (logHR) was used for time-to event data ${ }^{21-22}$. For the pooled analysis, we calculated the $\mathrm{I}^{2}$ statistic, which describes the percentage of total variation across studies caused by heterogeneity ${ }^{21}$. Low, moderate, and high levels of heterogeneity correspond approximately to $\mathrm{I}^{2}$ values of $25 \%, 50 \%$ and $75 \%$, respectively ${ }^{21}$. We used the fixed effect model when the $l^{2}$ was $<49.9 \%$ and the randomeffect model when $l^{2}$ was $\geq 50 \%$. Available information was summarized and based on ITT whenever possible. A qualitative description of adverse effects was provided whenever possible. Statistical significance was set at $p<0.05$. All statistical analyses were performed with Review Manager version 5.0 (RevMan, The Cochrane Collaboration).

\section{Results}

Tables 1, 2 and 3 shows the main findings for OS, response rate, hematological and non-hematological toxicity in RCTs included in the review.

\section{MP versus MD}

Three RCTs evaluating MP versus MD were included in the analysis ${ }^{29,31,39}$. Although no significant differences were observed between the two treatments in OS (3 RCT HR 0.95; 95\% Cl, 0.82-1.10; $\left.1^{2}, 0 \%\right)^{29,31,39}$, CR rate (2 RCTs, 389 patients: RR 0.35; 95\% Cl, 0.10-1.25; I2, $0 \%$ ) or hematological toxicity (2 RCTs, 415 patients: RR 1.15; 95\% Cl, 0.77-1.74; $\left.1^{2}, 24 \%\right)^{29,31}$, a higher PR rate (3 RCTs, 855 patients: RR 1.54; 95\% Cl, 1.32-1.80; $\left.I^{2}, 17 \%\right)^{29,31,39}$ with fewer non-hematological toxicities (2 RCTs, 415 patients: RR 2.15; 95\% Cl, 1.36-3.41; I $^{2}$, $46 \%)^{29,31}$ was observed in patients treated with MD. However, thrombocytopenia was lower in the MD group in one trial (RR 0.70; $95 \% \mathrm{Cl}, 0.54-0.91)^{39}$. A non-significant trend towards a higher rate of severe bacterial infections was also found in patients treated with MD in one RCT (RR 1.90; 95\% Cl, 0.98-3.65) ${ }^{29}$. However, two studies reported that non-hematological 
Table 1. Main findings for overall survival

\begin{tabular}{|c|c|c|c|c|}
\hline Reference & Intervention & Comparison & Hazard ratio (95\%CI)* & Heterogeneity $\mathbf{I}^{\mathbf{2}}$ \\
\hline $18,33,39$ & $\begin{array}{c}\text { Combination regimen (MP/MD) } \\
\text { Thalidomide* }\end{array}$ & MP & $0.79(0.66-0.96)$ & $86 \%$ \\
\hline 23 & BMP** & MP & $0.61(0.42-0.89)$ & - \\
\hline $34,36,44$ & MD & MP & $0.95(0.82-1.10)$ & $0 \%$ \\
\hline 42 & $\begin{array}{c}\text { Chemotherapy regimens without } \\
\text { melphalan (prednisone+ } \\
\text { bendamustine) }\end{array}$ & MP & $1.0(0.58-1.73)$ & - \\
\hline $\begin{array}{c}28-33,35,37, \\
38,40,41,43,45\end{array}$ & $\begin{array}{c}\text { More aggressive chemotherapy } \\
\text { regimens }\end{array}$ & MP & $0.95(0.88-1.03)$ & $0 \%$ \\
\hline
\end{tabular}

BMP: Bortezomib/Melphalan/Prednisone; MP: Melphalan/Prednisone; MD: Melphalan/Dexhamethasone.

*Hazard Ratio and $95 \%$ confidence intervals (Cl) were calculated using the generic inverse variance.

**Favoring this intervention.

Table 2. Main findings for response to therapy

\begin{tabular}{|c|c|c|c|c|c|}
\hline Reference & Intervention & Comparison & Type of response & Relative risk $(95 \% \mathrm{CI})^{*}$ & Heterogeneity $\left.\right|^{2}$ \\
\hline $\begin{array}{l}18,33,39,46 \\
18,33,39,46\end{array}$ & $\begin{array}{l}\text { Combination regimen } \\
\text { (MP/MD) + Thalidomide** }\end{array}$ & MP & $\begin{array}{l}\text { Complete response } \\
\text { At least partial response }\end{array}$ & $\begin{array}{l}3.44(1.86-6.39) \\
1.67(1.28-2.17)\end{array}$ & $\begin{array}{l}53 \% \\
74 \%\end{array}$ \\
\hline 23 & BMP & MP & $\begin{array}{c}\text { Complete response } \\
\text { At least partial response }\end{array}$ & $\begin{array}{l}8.35(4.68-14.89) \\
1.30(1.06-1.59)\end{array}$ & - \\
\hline $\begin{array}{c}34,36 \\
34,36,44\end{array}$ & $M D^{* *}$ & MP & $\begin{array}{c}\text { Complete response } \\
\text { At least partial response }\end{array}$ & $\begin{array}{l}0.35(0.10-1.25) \\
1.54(1.32-1.80)\end{array}$ & $\begin{array}{l}0 \% \\
17 \%\end{array}$ \\
\hline $34,42,45$ & $\begin{array}{l}\text { Chemotherapy regimens } \\
\text { without melphalan }\end{array}$ & MP & Complete response & $0.99(0.10-9.46)$ & $78 \%$ \\
\hline $\begin{array}{c}28-33,35,37 \\
38,40,41,43,45\end{array}$ & $\begin{array}{c}\text { More aggressive } \\
\text { chemotherapy regimens }\end{array}$ & MP & $\begin{array}{l}\text { Complete response } \\
\text { At least partial response }\end{array}$ & $1.06(0.49-2.41)$ & $75 \%$ \\
\hline
\end{tabular}

BMP: Bortezomib/Melphalan/Prednisone; MP: Melphalan/Prednisone; MD: Melphalan/Dexhamethasone.

*Relative Risk and $95 \%$ confidence intervals (CI) for dichotomous primary outcomes were calculated by the Mantel-Haenszel fixed-effects model when $R^{2}<50 \%$.

Relative Risk and $95 \%$ confidence intervals (Cl) for dichotomous primary outcomes were calculated by the Mantel-Haenszel random-effects model when $\mathrm{I}^{2}>50 \%$,

**Favoring this intervention.

Table 3. Main findings for hematological and non-hematological toxicity (grade 3-4)

\begin{tabular}{|c|c|c|c|c|}
\hline Reference & Intervention & Comparison & $\operatorname{RR}(95 \% \mathrm{CI}) *$ & Heterogeneity $\left.\right|^{2}$ \\
\hline \multicolumn{5}{|c|}{ Hematological toxicity } \\
\hline $18,33,39$ & $\begin{array}{c}\text { Combination regimen (MP/MD) + } \\
\text { Thalidomide** }\end{array}$ & MP & $0.79(0.19-3.29)$ & $97 \%$ \\
\hline 23 & BMP & MP & $1.11(0.86-1.44)$ & - \\
\hline 34,36 & $\mathrm{MD}$ & MP & $1.15(0.77-1.74)$ & $24 \%$ \\
\hline $32,34,35,40$ & More aggressive chemotherapy regimens & MP & $1.23(0.85-1.80)$ & $88 \%$ \\
\hline \multicolumn{5}{|c|}{ Non-hematological toxicity } \\
\hline $18,33,39$ & $\begin{array}{l}\text { Combination regimen } \\
\text { (MP/MD) + Thalidomide** }\end{array}$ & MP & $2.14(1.80-2.55)$ & $0 \%$ \\
\hline 23 & BMP & MP & $\begin{array}{c}1.27(0.68-2.37) \\
\text { (data for overall grade } 3-4 \text { toxicity) }\end{array}$ & - \\
\hline 34,36 & $M D^{* *}$ & MP & $2.15(1.36-3.41)$ & $46 \%$ \\
\hline $32,34,37$ & More aggressive chemotherapy regimens & MP & $1.46(0.90-2.37)$ & $91 \%$ \\
\hline
\end{tabular}

BMP: Bortezomib/Melphalan/Prednisone; MP: Melphalan/Prednisone; MD: Melphalan/Dexhamethasone.

*Relative Risk and 95\% confidence intervals (Cl) for dichotomous primary outcomes were calculated by the Mantel-Haenszel fixed-effects model when $2^{2}<50 \%$.

Relative Risk and $95 \%$ confidence intervals (Cl) for dichotomous primary outcomes were calculated by the Mantel-Haenszel random-effects model when I2 $>50 \%$.

**Favoring this intervention.

toxicity was significantly higher in patients treated with $M D$, mainly due to infections and hyperglycemia ${ }^{31,39}$. One RCT found that PFS was 21.1 versus 22.9 months (MD - HR 1.80, 95\% Cl, -2.27 to $-1.33 ; p<0.01)^{29} ; 15.9$ versus 23.3 months $(p=0.35)^{31}$; and 1.8 versus 1.9 years (HR 0.88, 95\% Cl, 0.72-1.07; $p=0.2$ ) for induction therapy and 2.8 versus 2.1 years (HR $0.61,95 \%$ $\mathrm{Cl}, 0.47-0.79 ; \mathrm{p}=0.0002$ ) for maintenance therapy ${ }^{39}$.

\section{MP versus MPT}

Seven studies comparing MP and MPT were identified $^{13,14,29,34,41,42,44}$, one of which was an update of a previously published study ${ }^{14}$. Another trial did not report the number of participants randomized and analyzed in each arm and was excluded from the analysis ${ }^{42}$. A non-significant trend towards longer OS was observed in MPT-treated patients when 4 RCTs were pooled (HR $\left.0.80 ; 95 \% \mathrm{Cl}, 0.53-1.20 ; 1^{2}, 84 \%\right)$; however, the patients included in the four trials were very heterogeneous, which may have skewed the results 13,29,34,44 (figure 2a). When one RCT was excluded ${ }^{34}$, a significant difference in OS favoring MPT was found (HR 0.80; 95\% $\left.\mathrm{Cl}, 0.53-1.22 ; \mathrm{I}^{2}, 0 \%\right)$. When five RCTs, with a total of 1335 patients, were pooled, higher CR (RR 3.75; 95\% $\mathrm{Cl}, 2.07-6.77 ; \mathrm{I}^{2}, 40 \%$ ) (figure $2 \mathrm{~b}$ ) and $\mathrm{PR}$ rates (RR $\left.1.72 ; 95 \% \mathrm{Cl}, 1.37-2.15 ; \mathrm{I}^{2}, 70 \%\right)$ were attained with 


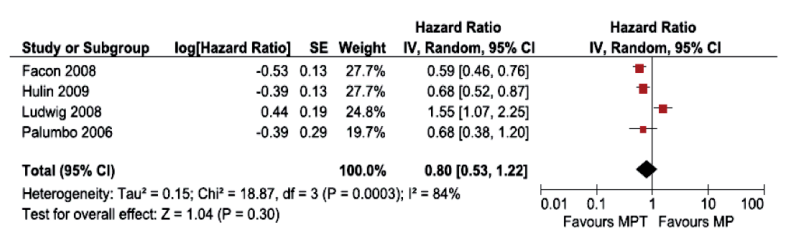

Figure 2a. Overall survival obtained from pooled analysis of MP versus MPT.

$\mathrm{MPT}^{13,29,34,41,44}$.

In four RCTs, median PFS was significantly higher in patients treated with MPT: (HR 0.51; $95 \% \mathrm{Cl}, 0.35-$ $0.75)^{13}, 17.8$ versus 27.5 months (HR $\left.0.45 ; p<0.0001\right)^{29}$, 24.1 versus 18.5 months (HR 0.62; $p=0.001)^{44}$, and 10 versus 13 months $(p<0.02)^{41}$. Conversely, in a fifth trial, median PFS was 16.7 and 20.7 months for the TD and MP groups, respectively (HR 1.30; 95\% Cl, 0.95-1.78) 34 . The proportion of patients without progressive disease at 12 and 24 months was $59 \%(95 \% \mathrm{Cl}, 51-68 \%)$ and $41 \%(95 \% \mathrm{Cl}, 33-51 \%)$ for those treated with TD and $63 \%(95 \% \mathrm{Cl}, 55-72 \%)$ and $48 \%(95 \% \mathrm{Cl}, 40-58 \%)$ for those treated with $\mathrm{MP}^{34}$.

In three RCTs with a total of 860 patients, no significant differences were found in grade 3-4 hematological toxicities (RR 0.79; 95\% Cl, 0.19-3.29; $\left.1^{2}, 97 \%\right)$; however, greater differences were observed in nonhematological toxicities (RR 2.14; 95\% Cl, 1.80-2.55; $\left.1^{2}, 0 \%\right)^{13,29,34}$. Thrombosis/embolism was significantly

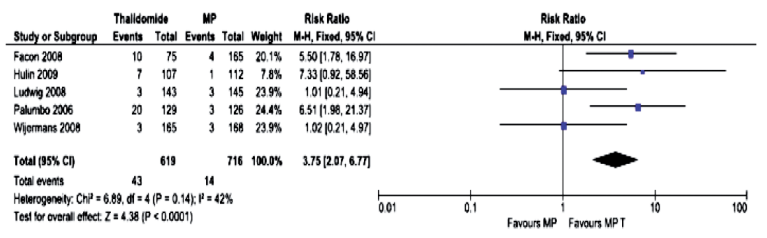

Figure 2b. Pooled analysis for response obtained for MP versus MPT.

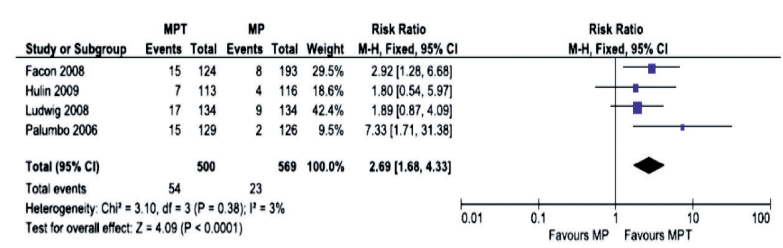

Figure 3a. Adverse events (thrombosis/embolism) observed in MP versus MPT.

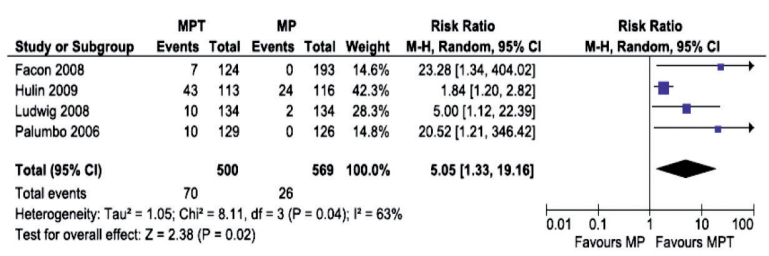

Figure $\mathbf{3 b}$. Pooled analysis for adverse event (peripheral neuropathy) in MP versus MPT. higher in the MPT group in four RCTs with 1069 patients (RR 2.69; 95\% Cl, 1.68-4.33; 12, 3\%) ${ }^{13,29,34,44}$. However, no significant difference was found between the two treatment groups in the two RCTs, with 523 patients, with available data on pulmonary embolism (RR 1.68; $\left.95 \% \mathrm{Cl}, 0.30-9.35 ; \mathrm{I}^{2}, 29 \%\right)^{13,34}$ (figure 3a). Finally, in four trials with a total of 1069 patients, peripheral neuropathy was significantly higher in the MPT group (RR 5.05; 95\% Cl, 1.33-19.16; $1^{2}, 63 \%$ ) (figure 3b) $13,29,34,44$.

\section{MP versus BMP}

Only one RCT, including 668 patients, assessed BMP compared to $\mathrm{MP}^{18}$. Both OS and PFS were longer in the BMP group (OS: HR 0.61; 95\% Cl, 0.42-0.89; PFS: HR 0.48; $95 \% \mathrm{Cl} ; 0.41-0.56)$. According to the EBMT (European Group for Blood and Marrow Transplantation) criteria, higher rates for both $C R$ and $P R$ were also attained with BMP (CR: RR 8.35; 95\% Cl, 4.68-14.89; $p=0.0001 ;$ PR: RR 1.30; $95 \% C l, 1.06-1.59 ; p=0.01$ ), while according to the International Uniform Response Criteria (IURC), only CR rate was higher for BMP (RR 8.39; 95\% Cl, 4.82-14.60; $p=0.00001$ ). The median duration of response was 19.9 months for the BMP group and 13.1 months for the control MP group ( $p=$ ns). The median duration of response among patients attaining a CR was 24.0 months in the BMP group and 12.8 months in the MP group (no $p$ value reported). No significant differences were found between the two groups regarding death during treatment (5\% and $4 \%$ respectively), treatment-related deaths ( $1 \%$ and $2 \%)$, overall grade 3-4 toxicities (RR 1.27; 95\% Cl, 0.68-2.37) or grade 3-4 hematological toxicity (RR 1.11; $95 \% \mathrm{Cl}$, $0.86-1.44)$. Anemia was significantly reduced in patients treated with $\mathrm{BMP}(\mathrm{RR} 0.72 ; 95 \% \mathrm{Cl}, 0.56-0.92)$; however, grade 3-4 peripheral sensory neuropathy (RR 88.22; 95\% Cl, 5.45-1426.63) and herpes zoster infections (RR 3.19; 95\% Cl, 1.78-5.69) occurred more frequently in the BMP group. An update of the study ${ }^{43}$, with a median follow-up of 25.9 months, recently reported a median time to next treatment of 28.1 versus 19.2 months (HR 0.53; $p<0.000001)$, a treatmentfree interval of 16.6 versus 8.4 months (HR $0.54 ; p<$ 0.000001 ), and a 3 -year OS rate of $72 \%$ versus $59 \%$, for the BMP and MP groups, respectively. The BMP group had a $36 \%$ reduced RR of death compared to the MP group (HR 0.644; $p=0.0032$ ). Overall grade 3-4 adverse events and severe adverse events were similar 
in the two groups (RR 1.13; 95\% Cl, 0.94-1.36; $p=0.19$ and RR 1.19; $95 \% \mathrm{Cl}, 0.83-1.71 ; p=0.35)$. Peripheral neuropathy (all grades) was significantly higher in the BMP group (RR 88.22; 95\% Cl, 5.15-1477; $p=0.002$ ) but improved over time in $79 \%$ of cases by a median of 1.9 months; $60 \%$ of neurotoxic adverse events were resolved within a median of 5.7 months.

\section{MP versus other chemotherapy regimens without melphalan}

Only three studies, including a total of 860 participants, did not include melphalan in the second chemotherapy regimen ${ }^{29,37,40}$. One study compared MP to dexamethasone or dexamethasone plus IFN$a 2 b^{29}$; another compared MP to prednisone plus bendamustine ${ }^{37}$; and the third compared MP to VMCP and $\mathrm{BCNU}^{40}$. When the three studies were pooled, no significant difference between groups was found in the $C R$ rate ( $R R$ 0.99; $95 \% ~ C l, 0.10-9.46 ; 1^{2}, 78 \%$ ). After the first interim analysis, the regimen with dexamethasone was discontinued in the first study ${ }^{40}$. The study comparing prednisone plus bendamustine to $\mathrm{MP}^{37}$ found no significant difference in OS between the two groups (HR 1.0; 95\% Cl, 0.58-1.73). However, a significantly higher number of patients treated with prednisone plus bendamustine achieved a CR compared to those receiving MP ( $R R 2.55 ; 95 \% \mathrm{Cl}, 1.22-5.30)$. Time to disease progression was also longer in patients treated with prednisone plus bendamustine (14 versus 10 months; $p<0.02$ ). Frequency of anemia, leucopenia and thrombocytopenia were similar in the two groups.

The study comparing MP to dexamethasone-based therapies found no significant differences in OS or in the $C R$ and $P R$ rates at 6 months among the three treatment groups $^{29}$; however, the MP group had less grade 3-4 non-hematological toxicity than dexamethasone alone (RR 1.70; 95\% Cl, 1.05-2.76) and dexamethasone plus IFN-a2b (RR 1.67; 95\% Cl, 1.02-2.74).

\section{MP versus more aggressive chemotherapy regimens}

Thirteen RCTs, including 3736 patients and 17 different treatment arms, compared more aggressive chemotherapy regimens to MP23-28,30,32,33,35,36,38,40. The meta-analysis of all these studies found no significant differences in PR rates between MP and the other chemotherapy regimens (RR 1.06; 95\% Cl, 0.49-2.41; $\left.1^{2}, 75 \%\right)$. A subgroup analysis of seven RCTs, including a total of 1458 patients, comparing MP to regimens containing vincristine, melphalan, cyclophosphamide and prednisone or vincristine, BCNU, adriamycin and prednisone also found no significant differences in PR rates (RR 1.14; 95\% Cl, 0.96-1.36; $\left.\left.\right|^{2}, 53 \%\right)^{24,25,30,32,35,38,40}$. Results of a subgroup analysis of five of the RCTs, with 1395 patients, were similar (RR 1.09; 95\% Cl; 0.83-.43; $\left.\mathrm{I}^{2}, 83 \%\right)^{23-25,35,38}$. In addition, there was no difference in OS, either when all 13 RCTs were pooled or in either of the two subgroup analyses (HR 0.95; $95 \% \mathrm{Cl}$, 0.88$\left.1.03 ; I^{2}, 0 \%\right)$. A significant difference in OS was found in one study comparing MP with reduced-intensity SCT with melphalan (HR 0.74; 95\% Cl, 0.56-0.97) ${ }^{28}$.

When pooling fourRCTs, with 1236 patients, no significant differences were observed in grade 3-4 hematological toxicity (RR 1.23; 95\% Cl, 0.85-1.80) 27,28,30,35. Similarly, when three RCTs, with 1218 patients, were pooled, no differences were observed in grade 3-4 non hematological toxicity (RR 1.46; $95 \% \mathrm{Cl}, 0.90$ 2.37) 27,28,32. However, both hematological and nonhematological grade 3-4 toxicities were significantly higher in the group receiving reduced-intensity SCT with melphalan ${ }^{28}$.

\section{Discussion}

The introduction of SCT has represented a major step forward in treating MM. However, this progress has been limited to patients aged less than 65-70 years, and MP has remained the gold standard for elderly patients during the past three decades ${ }^{130-134}$. This situation may change in coming years with the introduction of novel drugs targeting the myeloma cell and its bone marrow microenvironment, such as thalidomide, other immunomodulatory drugs and bortezomib ${ }^{10}$. We have evaluated the effects of intervention in five groups: MP versus MD, MP versus MPT, MP versus BMP, MP versus other chemotherapy regimens without melphalan, and MP versus more aggressive chemotherapy regimens.

Our review identified three $\mathrm{RCTs} \mathrm{s}^{29,31,39}$ comparing MP to MD. Pooled data showed a significantly higher $\mathrm{PR}$ rate in the MD group; however, non-hematological toxicities were also higher with MD, with an increased rate of infections and hyperglicemia, and no differences in OS were observed, perhaps due to early mortality from non-myeloma-related causes. Since MD causes 
higher morbidity rates, these results have led investigators to reject MD as a new standard therapy.

Six studies included thalidomide-based regimens for treating MM patients who were ineligible for $\mathrm{SCT}^{18,19,33,39,46,47}$, one of which was an update of a previously published study ${ }^{19}$. The thalidomide-based regimens had higher ORR rates in four of these studies $^{18,33,39,46}$ and longer PFS in three ${ }^{18,33,46}$. Although OS was also longer in three of the studies ${ }^{18,33,39}$, this finding must be interpreted with caution since the studies were quite heterogeneous, due to the wide variety of thalidomide doses (100 to $400 \mathrm{mg} / \mathrm{d}$ ), the non-universal use of thalidomide as maintenance therapy until disease progression ${ }^{14,35}$, and the wide range of chemotherapy cycles used in combination with thalidomide (6 to 12 cycles). In fact, the use of thalidomide as induction and maintenance therapy has been shown to lead to acquired resistance to this agent ${ }^{135}$.

We found that non-hematological toxicities, mainly thromboembolic defects and peripheral neuropathy, were more frequent in patients receiving thalidomide. Along these same lines, a meta-analysis of trials using thalidomide-based therapy described a 9\% $(95 \% \mathrm{Cl}$, $6-13 \%)$ absolute increase in risk of venous thromboembolic events and a number needed to harm (NNH) of 11 (95\% Cl, 8-17); moreover, in six of ten RCTs using thalidomide as induction therapy, no difference was attributable to the non-use of thromboembolic prophylaxis $^{134}$. The same meta-analysis examined 13 RCTs, with 4144 previously untreated MM patients ${ }^{134}$; nine of these trials evaluated induction therapy and reported a significant improvement in progression endpoints with thalidomide. However, only two of the trials ${ }^{29,136}$ detected significant improvements in OS. The pooled HR for OS was 0.67 (95\% Cl, 0.56-0.81) when thalidomide was added to standard non-transplantation therapy, with a negative test for heterogeneity. The weighted RR for response to a thalidomide-containing-regimen was 1.5 , which translates to an absolute reduction in the risk of having less than a $24 \%$ PR. This suggests that an average of four patients $(95 \% \mathrm{Cl}, 3-6)$ need to be treated with thalidomide in order to obtain one additional response. The weighted RR for a CR to induction thalidomide was $2.82^{134}$.

Only one study compared MP to BMP and found improved ORR, PFS and OS with BMP ${ }^{18}$. This recent study was closed prematurely based on favorable results, and updated results were reported after a longer median follow-up of 25.9 months ${ }^{43}$. The update confirmed that BMP was associated with a $36 \%$ reduction in the risk of death, with median OS not reached in either arm. Furthermore, BMP showed efficacy regardless of poor prognostic characteristics, including cytogenetic analysis (high-risk defined as $\mathrm{t}[4 ; 14]$, t[14;16], del[17p]) by FISH ${ }^{43}$. The update also evaluated response to subsequent therapies, including bortezomib retreatment. Importantly, BMP-treated patients were able to respond to bortezomib-based salvage and immunomodulatory drug-based rescue therapy in similar proportions to patients receiving only MP. This suggests that the initial use of proteasome agent combinations does not necessarily result in significant resistance at a later date ${ }^{43}$.

Three studies did not include melphalan in their schedules $29,37,40$; there were no differences in ORR or in OS rates in the group of patients who were treated with dexamethasone or bendamustine without melphalan; nevertheless, there was a higher CR rate and PFS in those receiving bendamustine ${ }^{37}$.

The 13 trials using more aggressive chemotherapy regimens were carried out several decades ago and reported no improvement in any of the outcomes compared to MP, thus further demonstrating that adding more agents does not necessarily offer any advantages. These findings were similar to those previously reported by the Myeloma Trialists Collaborative Group, who described a non-significant difference in OS between patients allocated to combination chemotherapy or MP. The estimate for proportional reduction in the annual odds of death is $1.5 \%$ in favor of combination chemotherapy, but the $95 \% \mathrm{Cl}$ for this reduction ranges from an $8 \%$ benefit for chemotherapy to a $5 \%$ benefit for $\mathrm{MP}$; this range corresponds to an absolute $1 \%$ difference in OS at 3 years ${ }^{9}$.

Lenalidomide was not included in our analysis because no RCTs have compared it to MP; however, this novel component seems to offer some advantages over thalidomide, especially in terms of neurotoxicity and ORR 137,138. The Eastern Cooperative Oncology Group (ECOG) E4A03 phase III trial randomized 445 patients with newly diagnosed MM to lenalidomide plus high-dose dexamethasone (RD) or lenalidomide plus low-dose dexamethasone (Rd). The primary analysis demonstrated a higher ORR 
with the high-dose than with the low-dose regimen (79\% vs. 69\%), but the difference did not reach the predefined ORR of $15 \%$ for the low-dose arm. In contrast, the 2-year OS rate for the low-dose arm was $88 \%$, compared to $78 \%$ in the high-dose arm $(p=0.007)^{139}$. In fact, these results allowed the study to be closed prematurely. The encouraging data obtained with lenalinomide will provide the basis for new RCTs, which may lead to its use in patients ineligible for SCT. MP thus continues to be the backbone of treatment for patients not eligible for SCT although newer combinations may improve results and should be considered as part of standard therapy. Our conclusions are supported by the guidelines for the management of MM patients ineligible for standard high-dose chemotherapy with autologous SCT recently published by the International Myeloma Working Group ${ }^{140}$.

\section{Quality of the evidence}

Our systematic review and meta-analysis was based on RCTs reported in the literature or presented at major international cancer or hematology conferences. As such, the study has a number of important limitations. Firstly, it is vulnerable to publication bias, nevertheless, the funnel plot decline this observation (see Annex 3). We attempted to minimize the potential impact of publication bias by including large and well-designed search strategies, but negative trials or studies conducted in developing countries may have been inadvertently excluded. Since our analysis was limited to published data, in some cases, we had incomplete information. Our integrative review was based on aggregating study and sub-study data, not on individual patient information. As a result, our time-to-event analysis was limited and it was not possible to explore whether patient factors contributed to the statistical heterogeneity we observed in some of the outcome analyses. Finally, the quality of a meta-analysis is always subject to the studies included in the review. All our included studies were opened and only four RCTs had a low risk of bias; the other 18 trials were judged to have an unclear risk of bias, mainly because the description of the method used for generating the allocation sequence and/or concealing the allocation was unclear. The absence of blinding had minimal relevance for the analysis of outcomes such as OS or PFS but may have affected adverse event rates. Furthermore, most RCTs did not calculate sample size, which represents a potential source of imprecision, and some of the studies reported preliminary results for which it was impossible to obtain predefined statistical parameters ${ }^{18}$.

\section{Acknowledgments}

This study was supported by an independent grant (009-2008) from the Foundation for Clinical and Translational Cancer Research (FICMAC) (Bogotá, Colombia). FICMAC had no such involvement on the text. We thank Mrs. Reneé O'Brate for helpful comments and editorial support.

\section{Statement of authors' contributions}

- Study proposal (all authors),

- Search strategy (LR, AFC),

- Selection of studies to include (MLR, JFC, CPC, CA, $L R, J B, A F C$ ),

- Assessment and extraction of data from RCTs (MR, JFC, CPC, CA, LR, JB),

- Third assessor when necessary (AFC, HAB),

- Summary and analysis of data (LR, JB, $A F C$ ),

- Interpretation of data (MLR, JFC, CPC, CA, LR, JB, AMC, AFC, HAB),

- Critical review (MLR, AFC, HAB),

- Writing and approval of final review (all authors). 
Annex 1. Characteristics of RCTs included in the review

\begin{tabular}{|c|c|c|c|c|}
\hline Study & Methods & Participants & Interventions & Outcomes \\
\hline \begin{tabular}{|l} 
Blade 1990 \\
\end{tabular} & $\begin{array}{l}\text { Multicenter RCT, open } \\
\text { label study with parallel } \\
\text { design, unblinded. } \\
\mathrm{N}=386\end{array}$ & $\begin{array}{l}\text { Naive patients with MM } \\
\text { diagnosis according to the } \\
\text { Chronic Leukemia Myeloma } \\
\text { Task Force (1973). Patients with } \\
\text { asymptomatic disease were } \\
\text { excluded. }\end{array}$ & $\begin{array}{l}\text { a. MP' alterning with } \\
\text { b. VCMP'NBAP' (courses were administered } \\
\text { at 4-weeks intervals) }\end{array}$ & 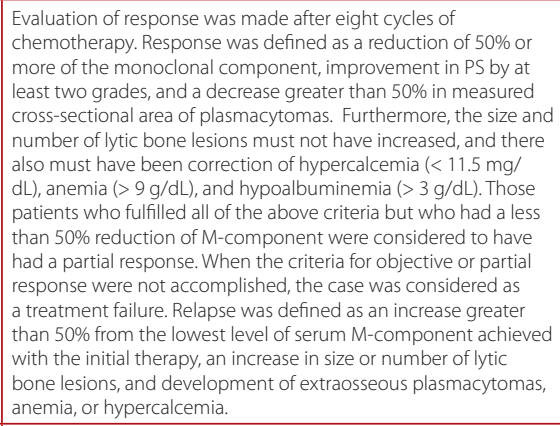 \\
\hline \begin{tabular}{|l} 
Blade 1993 \\
\end{tabular} & \begin{tabular}{|l|} 
Multicenter RCT, open \\
label, unblinded. \\
N=449 (248 and \\
239 patients were \\
randomized to receive \\
MP' and alternating courses of VCMP'NBAP', \\
respectively).
\end{tabular} & $\begin{array}{l}\text { Naiive patients with MM } \\
\text { diagnosis according to the } \\
\text { Chronic Leukemia Myeloma } \\
\text { Task Force (1973). Patients with } \\
\text { asymptomatic disease were } \\
\text { excluded. }\end{array}$ & $\begin{array}{l}\text { MP' alterning with } \\
\text { VCMP'NBAP' (courses administered at } \\
\text { 4-weeks intervals and patients with serum } \\
\text { creatinine }>2 \mathrm{mg} / \mathrm{dL} \text { initially received the } \\
\text { alkylating agents at half doses) }\end{array}$ & 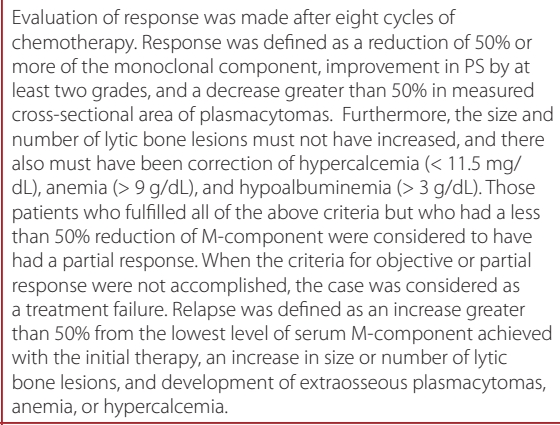 \\
\hline Boccadoro 1991 & $\begin{array}{l}\text { Multicenter RCT, open } \\
\text { label. } \\
\mathrm{N}=304\end{array}$ & $\begin{array}{l}\text { Naiive patients with MM } \\
\text { according to the SWOG criteria. } \\
\text { MM was classified using the } \\
\text { Durie and Salmon staging } \\
\text { system. }\end{array}$ & $\begin{array}{l}\text { MP2 } \\
\text { VMCP2/NBAP2 (induction treatment was } \\
\text { administered at 28-day intervals for } 12 \\
\text { months) }\end{array}$ & $\begin{array}{l}\text { Response was defined as a reduction of } 50 \% \text { or more in the } \\
\text { M-component. Relapse was defined as an increase greater than } \\
100 \% \text { from the lowest level of serum M-component, or a raise in } \\
\text { the size or number of lytic bone lesions. Progression were defined } \\
\text { for never-responding population as an increase greater than } 25 \% \\
\text { in the M-component or an increase in size or number of lytic } \\
\text { bone lesions during induction treatment. }\end{array}$ \\
\hline Cavo 2002 & \begin{tabular}{|l|} 
Multicenter RCT, open \\
label, unblinded. \\
$\mathrm{N}=542$ (patients were \\
assigned in blocks of six \\
to receive one of three \\
regimens consisting \\
of either MP3 alone, VAD \\
alternating with MP3 or \\
VND alternating with \\
MP3). \\
Randomization to the \\
three arms of the study \\
was 1:1:1. Patients were \\
planned to receive \\
8-monthly courses of \\
chemotherapy. Of the \\
527 eligible patients, \\
179 were randomly \\
assigned to MP3, 174 to \\
arm alternating VAD/MP3, \\
and 174 to alternating \\
VND/MP3.
\end{tabular} & $\begin{array}{l}\text { Naïve patients with MM } \\
\text { diagnosis according to the } \\
\text { Chronic } \\
\text { Leukemia Myeloma Task Force } \\
\text { (1973) } \\
\text { Patients were eligible for } \\
\text { randomization if they had } \\
\text { symptomatic MM and } \\
\text { measurable M-protein in the } \\
\text { serum and/or urine. Reasons } \\
\text { for exclusion included age } \\
>80 \text { years, severe heart } \\
\text { disease, hepatic dyfunction } \\
\text { or prior history of another } \\
\text { neoplasm. Patients with } \\
\text { smoldering myeloma, localized } \\
\text { plasmacytoma or plasma cell } \\
\text { leukemia were also excluded. }\end{array}$ & $\begin{array}{l}\text { MP3 } \\
\text { VAD } \\
\text { VND } \\
\text { Full drug doses were administered if } \\
\text { granulocytes }>2 \times 10^{9} / L \text { and platelets } \\
>100 \times 10^{9} / L \text {. Patients who completed the } \\
\text { induction chemotherapy phase of the } \\
\text { study and achieved an objective response } \\
\text { received recombinant interferon (IFN) } \mathrm{a}-2 \mathrm{~b} \\
\text { at the dose of } 3 \mathrm{MU}, \text { subcutaneously, three } \\
\text { times weekly, until evidence of progression. }\end{array}$ & $\begin{array}{l}\text { Response was evaluated according to the criteria of the Chronic- } \\
\text { Leukemia Myeloma Task Force and was based on M-protein } \\
\text { decrease at the end of induction chemotherapy as compared } \\
\text { with pre- treatment values. } \\
\text { An objective response was defined by a decrease in serum } \\
\text { or urinary M-protein concentration of at least } 50 \% \text { or } 75 \% \text {, } \\
\text { respectively, without other veidence of progression. Patients who } \\
\text { achieved only a } 25 \% \text { to } 50 \% \text { decrease in serum M-protein level or } \\
\text { at least } 50 \% \text { reduction in } 24 \text {-hour excretion of urinary light chains } \\
\text { were considered as having a minor response. } \\
\text { Stable disease, or no change, included less than } 25 \% \text { decrease in } \\
\text { serum M protein level or less than } 50 \% \text { reduction in Bence Jones } \\
\text { proteinuria. }\end{array}$ \\
\hline Cooper 1986 & $\begin{array}{l}\text { Multicenter RCT, with } \\
\text { parallel design and open } \\
\text { label. } \\
\mathrm{N}=615 \text { (patients were } \\
\text { randomized to receive } \\
\text { MCBP, sequentially-MCBP, } \\
\text { MCBPA or MP4) }\end{array}$ & $\begin{array}{l}\text { The diagnosis of MM was } \\
\text { established according to } \\
\text { the criteria of the Chronic } \\
\text { Leukemia-Myeloma Takk Force. } \\
\text { Any patient had received } \\
\text { prior chemotherapy and } \\
\text { prior radiation treatment of } \\
\text { symptomatic lesions was } \\
\text { allowed if the field did not } \\
\text { exceed } 150 \mathrm{~cm}^{2} \text { and if the } \\
\text { course of treatment was } \\
\text { completed before protocol } \\
\text { entry. }\end{array}$ & $\begin{array}{l}\text { MCBP (repeated every } 42 \text { days) } \\
\text { Seq-MCBP (repeated every } 84 \text { days) } \\
\text { MCBPA (repeated every 42 days) } \\
\text { MP4 (repeated every } 28 \text { days) }\end{array}$ & $\begin{array}{l}\text { Complete response was defined as a reduction of serum or } \\
\text { urinary M-protein to } 50 \% \text { of the initial value, healing of bone } \\
\text { lesions, or } 50 \% \text { decrease in the area of measured soft-tissue } \\
\text { lesions. Indirect responses included improvement in hemoglobin } \\
\text { level, creatinine, serum calcium, PS, or pain. }\end{array}$ \\
\hline
\end{tabular}




\begin{tabular}{|c|c|c|c|c|}
\hline Study & Methods & Participants & Interventions & Outcomes \\
\hline Facon 2005 & 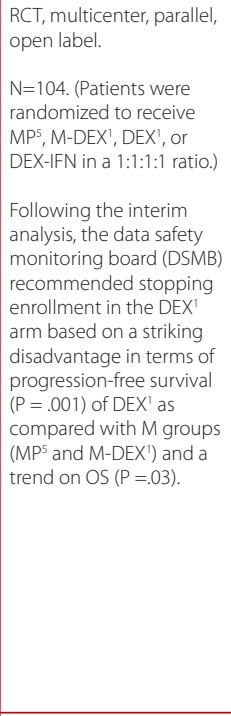 & $\begin{array}{l}\text { Patients aged between } 65 \\
\text { and } 75 \text { years and fulfilling a } \\
\text { diagnosis of stage II or III MM } \\
\text { according to the Durie and } \\
\text { Salmon criteria, or stage I MM } \\
\text { patients if they met one of } \\
\text { the criteria defining high-risk } \\
\text { stage I. } \\
\text { Patients were previously } \\
\text { untreated (except the } \\
\text { minimum dose of radiotherapy } \\
\text { to localized lesions required to } \\
\text { relieve symptoms). } \\
\text { Patients were excluded } \\
\text { if they met the criteria of } \\
\text { primary amyloidosis, had } \\
\text { a prior history of another } \\
\text { neoplasm or of seizure, had } \\
\text { significant cardiac, psychiatric } \\
\text { or hepatic dysfunction, had a } \\
\text { contraindication to high-dose } \\
\text { steroids. }\end{array}$ & $\begin{array}{l}\text { a. MP5: Courses were administered at } \\
6 \text {-week intervals for } 12 \text { cycles. } \\
\text { The neutrophil count must have reached } \\
1.5 \times 10^{9} / \mathrm{L} \text { and the platelet count } 100 \times 10^{9} / \mathrm{L} \\
\text { before full-dose chemotherapy was given. } \\
\text { A } 50 \% \text { melphalan reduction was performed } \\
\text { if the neutrophil count was between } \\
1.0 \times 10^{9} / \mathrm{L} \text { and } 1.5 \times 10^{9} / \mathrm{L} \text { or the platelet count } \\
\text { between } 50 \times 10^{9} / \mathrm{L} \text { and } 100 \times 10^{9} / \mathrm{L} \text {. } \\
\text { b. DEX': On } 12 \text { cycles. The dose could } \\
\text { be reduced by } 50 \% \text { ( } 20 \mathrm{mg} / \mathrm{d} \text { ) in case of } \\
\text { toxicity } \\
\text { c. M-DEX': The doses of melphalan and } \\
\text { dexamethasone and dose adjustments } \\
\text { for side effects were the same as those } \\
\text { presented for the MP5 and dexamethasone } \\
\text { regimens. } \\
\text { d. DEX-IFN: IFN was permanently } \\
\text { discontinued in the case of an emergence } \\
\text { of cardiac dysfunction or an occurrence of } \\
\text { seizures or psychiatric complications. } \\
\text { Protocol doses of IFN were reduced by } \\
20 \% \text { to } 50 \% \text { in patients who experienced } \\
\text { significant fatigue or other symptoms } \\
\text { suggesting significant toxicity. The dose was } \\
\text { subsequently reescalated if this was feasible. }\end{array}$ & $\begin{array}{l}\text { Overall survival, progression-free survival, survival after } \\
\text { progression, response rates, and toxicities. Any response } \\
\text { required an improvement in bone pain and performance status, } \\
\text { correction of hypercalcaemia, and no increase in size or number } \\
\text { of lytic bone lesions. } \\
\text { Partial response: reduction in the size of soft-tissue } \\
\text { plasmacytomas, } 50 \% \text { reduction in serum monoclonal protein and } \\
24 \text {-hour urinary light chain excretion by } 75 \% \text { or more. } \\
\text { Complete response: absence of the original monoclonal protein } \\
\text { in serum and urine by immunofixation, less than } 5 \% \text { plasma } \\
\text { cells in a bone marrow aspirate, disappearance of soft tissue } \\
\text { plasmacytomas. } \\
\text { Progressive disease: more than } 25 \% \text { increase in serum } \\
\text { monoclonal protein, } 50 \% \text { increase in the } 24 \text {-hour urinary light } \\
\text { chain excretion, increase in the size or new of bone lesions or } \\
\text { soft-tissue plasmocytomas, hypercalcaemia not attributable to } \\
\text { any other cause. } \\
\text { Stable disease: Patients not meeting the criteria of either partial } \\
\text { or complete response or progressive disease. }\end{array}$ \\
\hline Facon 2006 & $\begin{array}{l}\text { RCT, multicenter, open } \\
\text { label. } \\
\mathrm{N}=447 \text { (patients were } \\
\text { randomly assigned, } 126 \\
\text { assigned to MP5, } 125 \text { to } \\
\text { MP5 plus thalidomide } \\
\text { and } 126 \text { to MEL } 100 . \text {.) }\end{array}$ & $\begin{array}{l}\text { Untreated patients aged } \\
\text { between } 65 \text { and } 75 \text { years and } \\
\text { fulfilling a diagnosis of stage } \\
\text { II or III MM according to the } \\
\text { Durie and Salmon criteria, or } \\
\text { stage I MM patients if they met } \\
\text { one of the criteria defining } \\
\text { high-risk stage I patients. } \\
\text { If younger, were included } \\
\text { if they were ineligible for } \\
\text { high-dose treatment.Exclusion } \\
\text { criteria: previous history of } \\
\text { another neoplasm (except } \\
\text { basocellular cutaneous or } \\
\text { cervical epithelioma); primary } \\
\text { or associated amyloidosis; } \\
\text { a WHO performance index } \\
\text { of } 3 \text { or greater, if unrelated } \\
\text { to MM; substantial renal } \\
\text { insufficiency with creatinine } \\
\text { serum concentration of } 50 \\
\text { mg/L or more; cardiac or } \\
\text { hepatic dysfunction; peripheral } \\
\text { neuropathy; or infection with } \\
\text { HIV, or hepatitis B or C. }\end{array}$ & 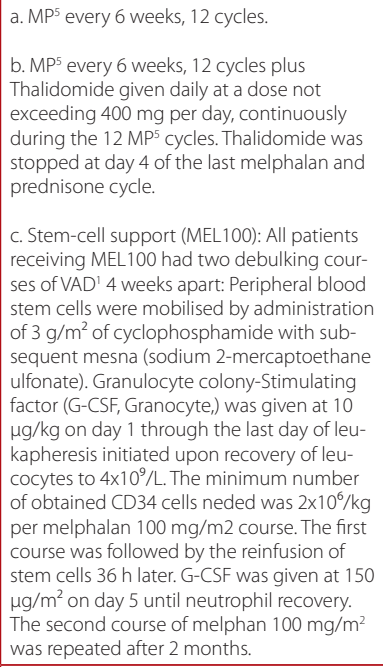 & $\begin{array}{l}\text { Overall survival, response, progression-free survival, survival after } \\
\text { progression and toxicity. } \\
\text { Complete response: absence of the original monoclonal } \\
\text { protein in serum and urine, less than } 5 \% \text { of plasma cells in a } \\
\text { bone-marrow aspirate, and the disappearance of soft-tissue } \\
\text { plasmacytomas } \\
\text { Progressive disease: } 25 \% \text { increase in the concentration of serum } \\
\text { monoclonal protein, } 50 \% \text { increase in the } 24 \text {-h urinary light chain } \\
\text { excretion, increase in the size or new bone lesions or soft-tissue } \\
\text { plasmacytomas, hypercalcaemia, not attributable to any cause } \\
\text { other than MM. } \\
\text { Best response at } 12 \text { months: the highest amount of disease } \\
\text { improvement achieved by a patient, except if progressive disease } \\
\text { had occurred during that period without response assessment at } \\
12 \text { months (between } 9 \text { and } 15 \text { months). }\end{array}$ \\
\hline Hansen 1985 & $\begin{array}{l}\text { RCT } \\
N=104 \\
M P^{6}=33 \\
M^{\prime} P^{1}=32 \\
\text { VBCMP }^{1}=31\end{array}$ & $\begin{array}{l}\text { All previously untreated } \\
\text { patients with a confirmed } \\
\text { diagnosis of MM were eligible. } \\
\text { Diagnostic criteria for MM: a) } \\
\text { more than } 3 \% \text { atypical plasma } \\
\text { cells in a bone marrow smear } \\
\text { combined with b) at least } 1 \\
\text { of the following } 3 \text { criteria: (i) } \\
\text { an M-component in serum } \\
\text { in a high concentration or (ii) } \\
\text { excretion of light chains in } \\
\text { the urine }>0.25 \text { g/ } 24 \text { h, or (iii) } \\
\text { osteolytic bone lesions. }\end{array}$ & $\begin{array}{l}\text { a. } M P^{6} \\
\text { b. } M P^{1} \\
\text { c. } V B C M P^{1}\end{array}$ & $\begin{array}{l}\text { Response: a decrease in M component concentration in serum } \\
\text { or urine of } 75 \% \text { or more; the osteolytic lesions must not have } \\
\text { enlarged }>25 \% \text { or increased in number, the serum calcium } \\
\text { concentration must have remained normal and a decrease of } \\
25 \% \text { or a normalization of an increased serum Creatinine and a } \\
25 \% \text { increase or a normalization of HB. }\end{array}$ \\
\hline Hernandez 2004 & $\begin{array}{l}\text { RCT, multicenter, open } \\
\text { label. } \\
\text { Only } 170\left(87 \mathrm{MP}^{1} \text { and }\right. \\
83 \mathrm{DEX})^{2} \text { patients were } \\
\text { evaluable for response. }\end{array}$ & $\begin{array}{l}\text { Diagnostic criteria of the } \\
\text { Chronic Leukemia Myeloma } \\
\text { Task Force of the National } \\
\text { Cancer Institute (1973) and be } \\
\text { diagnosed with symptomatic } \\
\text { MM. }\end{array}$ & $\begin{array}{l}\text { a. MP' } \\
\text { b. DEX }\end{array}$ & $\begin{array}{l}\text { Response rate, event-free survival, overall survival and toxicity. } \\
\text { Those patients who showed disappearance of the M-Component } \\
\text { by electrophoresis and }<5 \% \text { plasma cells in bone marrow were } \\
\text { considered complete responders. }\end{array}$ \\
\hline HJORT 1990 & $\begin{array}{l}\text { RCT, multicenter. } \\
\mathrm{N}=164 \mathrm{MP}^{5}=85 \\
\text { Multidrug chemotherapy } \\
(\mathrm{MDC})=79\end{array}$ & $\begin{array}{l}\text { Inclusion criteria: (A) serum } \\
\text { M-protein concentration above } \\
30 \mathrm{~g} / \mathrm{L}(\mathrm{lgG}) \text { or } 20 \mathrm{~g} / \mathrm{L}(\mathrm{lgA}) \text { and/ } \\
\text { or Bence Jones proteinuria }>1 \\
\mathrm{~g} / 24 \mathrm{~h} \text {. B) Bone marrow plasma } \\
\text { cells }>10 \% \text { and }(\mathrm{C}) \text { Osteolitic } \\
\text { bone lesions. A diagnosis of MM } \\
\text { was accepted if criteria A+B or } \\
\mathrm{A}+\mathrm{C} \text { were fulfilled. }\end{array}$ & $\begin{array}{l}\text { a. MP }{ }^{5} \text { every } 6 \text { weeks. } \\
\text { b. For patients randomized to MDC: } \\
\text { (i) stage II patients were given } \mathrm{VMCP}^{3} \text { every } \\
4 \text { weeks, } \\
\text { (ii) stage III patients were given } V B A P^{3} \text { and } \\
\text { VMCP }{ }^{3} \text { alternately every } 4 \text { weeks. }\end{array}$ & $\begin{array}{l}\text { Response remission: } 50 \% \text { reduction of the initial M-protein } \\
\text { concentration. } \\
\text { Time to response: from the start of treatment until the first } \\
\text { confirmed M-protein determination showing at least a } 50 \% \\
\text { reduction. } \\
\text { Relapse: increase in M protein of > } 20 \% \text { or the reappearance of a } \\
\text { vanished M-protein. }\end{array}$ \\
\hline
\end{tabular}




\begin{tabular}{|c|c|c|c|c|}
\hline Study & Methods & Participants & Interventions & Outcomes \\
\hline $\begin{array}{l}\text { Kildahl-Andersen } \\
1988\end{array}$ & $\begin{array}{l}\text { RCT, multicenter. } \\
\mathrm{N}=92 \\
\mathrm{VCCM}^{\top}=48 \\
\mathrm{MP}^{7}=44\end{array}$ & $\begin{array}{l}92 \text { Patients with MM diagnosed } \\
\text { according to the criteria } \\
\text { recommended by the Chronic } \\
\text { Leukemia-Myeloma Task Force } \\
\text { and the South West Oncology } \\
\text { Group. No patient received } \\
\text { prior chemotherapy. Staging } \\
\text { performed according to Durie } \\
\text { \& Salmon. }\end{array}$ & $\begin{array}{l}\text { a. } \mathrm{VCCM}^{1} \\
\text { b. } \mathrm{MP}^{7}\end{array}$ & $\begin{array}{l}\text { Median Survival, time to relapse, duration of remission, Response } \\
\text { rate. } \\
\text { The criteria for response were those adopted by the Chronic } \\
\text { Leukemia-Myeloma Task Force } 1973 \text {. }\end{array}$ \\
\hline Ludwig 2008 & $\begin{array}{l}\text { Multicenter, open label.N } \\
=289 \\
\mathrm{TD}^{1}=145 \\
\mathrm{MP}^{5}=144 \\
19 \text { and } 15 \text { withdrawals } \\
\text { respectively occurred } \\
\text { during follow up. }\end{array}$ & $\begin{array}{l}\text { Previously untreated active } \\
\text { MM not eligible for autologous } \\
\text { transplantation with Durie } \\
\text { Salmon stage II and III, and } \\
\text { stage I on high risk. } \\
\text { Exclusion criteria: } \\
\text { Extramedullary or solitary } \\
\text { plasmacytoma without } \\
\text { evidence of dissemination of } \\
\text { disease or with smouldering } \\
\text { myeloma, with more than } 3 \\
\text { irradiation fields, congestive } \\
\text { heart failure (NYHA III and IV), } \\
\text { acute infection, uncontrolled } \\
\text { medical condition. }\end{array}$ & $\begin{array}{l}\text { a. TD': standard doses on odd cycles and } \\
\text { same dose added on day } 15-18 \text { on even } \\
\text { cycles of } 28 \text { days. } \\
\text { b. MP': during a } 28 \text { to } 42 \text { day cycle. }\end{array}$ & $\begin{array}{l}\text { Progression-free survival, tolerance, response rates, time to } \\
\text { response, overall survival. } \\
\text { Evaluation of response, the EBMT criteria: Disappearance of } \\
\text { myeloma protein in serum and urine by immunofixation } \\
\text { maintained for a minimum of } 6 \text { weeks, }<5 \% \text { plasma cells in bone } \\
\text { marrow, no increase in lytic bone lesions, disappearance of soft } \\
\text { tissue plasmacytomas. } \\
\text { Progression of the disease: A greater than } 25 \% \text { increase in serum } \\
\text { paraprotein concentrationa and in } 24 \text {-hour urinary paraprotein } \\
\text { excretion, }>25 \% \text { increase in plasma cells, progressive bone } \\
\text { disease, hypercalcaemia not attributable to other causes than } \\
\text { myeloma. }\end{array}$ \\
\hline Osterborg 1989 & $\begin{array}{l}\text { RCT, multicenter. } \\
N=86 \\
M P^{5}=44 \\
\text { VCMP }^{4} \text { NBAP }^{4}=42\end{array}$ & $\begin{array}{l}\text { Patients with MM stage III. } \\
\text { Diagnosis: When at least } \\
\text { two of following criteria } \\
\text { was met: } 1 \text {. A monoclonal } \\
\text { immunoglobulin peak with a } \\
\text { subnormal concentration of } \\
\text { at least one non-monoclonal } \\
\text { immunoglobulin class (IgG, IgM } \\
\text { and lgA) } 2 .>10 \% \text { plasma cells in } \\
\text { the bone marrow. 3. Osteolytic } \\
\text { and or osteoporotic bone } \\
\text { lesions compatible with MM. }\end{array}$ & $\begin{array}{l}\text { a. VCMP4 alternating every } 3 \text { weeks with } \\
\text { VBAP4. When response was achieved, } \\
\text { interval between the cycles was prolonged } \\
\text { to } 6 \text { weeks. } \\
\text { b. MP5 administered at } 6 \text { weeks interval, } \\
\text { continued until progression or relapse. }\end{array}$ & $\begin{array}{l}\text { The criteria for response were those adopted by the Chronic } \\
\text { Leukemia-Myeloma Task Force } 1973 .\end{array}$ \\
\hline Palumbo 2006 & $\begin{array}{l}\text { RCT, multicenter. } \\
\\
\mathrm{MPT}^{1}=129 \\
\mathrm{MP}^{8}=126 \\
\text { There were } 10 \\
\text { withdrawals }(7 \text { lost to } \\
\text { follow up in } \mathrm{MP}^{8} \text { ) }\end{array}$ & $\begin{array}{l}\text { Inclusion criteria: previously } \\
\text { untreated } \\
\text { MM patients older than } 65 \\
\text { years (or younger but unable } \\
\text { to undergo transplantation), } \\
\text { Durie and Salmon stage II or } \\
\text { III myeloma, and measurable } \\
\text { disease. } \\
\text { Exclusion criteria: another } \\
\text { cancer, psychiatric disease } \\
\text { and any grade } 2 \text { peripheral } \\
\text { neuropathy. }\end{array}$ & $\begin{array}{l}\text { a. MP8: every } 4 \text { weeks for six cycles. In } \\
\text { this group, patients who had progressive } \\
\text { disease or relapse were permitted to } \\
\text { crossover to receive thalidomide as salvage } \\
\text { treatment. } \\
\text { b. MPT' every } 4 \text { weeks for six cycles. }\end{array}$ & $\begin{array}{l}\text { Clinical response rates, event-free survival, overall survival, } \\
\text { prognostic factors, time to the first evidence of response, } \\
\text { incidence of any grade } 3 \text { or higher adverse events. } \\
\text { Response criteria of the European Group for Blood and Marrow } \\
\text { Transplantation/International Bone Marrow Transplant Registry } \\
\text { were used. }\end{array}$ \\
\hline Palumbo 2008 & $\begin{array}{l}\text { RCT, multicenter. } \\
\mathrm{N}=331 \\
\mathrm{MPT}^{1}=167 \\
\mathrm{MP}^{8}=164\end{array}$ & $\begin{array}{l}\text { Patients with previously } \\
\text { untreated MM who were older } \\
\text { than } 65 \text { years or younger not } \\
\text { candidates for transplant, Durie } \\
\text { and Salmon stage II or III MM, } \\
\text { with measurable disease. }\end{array}$ & $\begin{array}{l}\text { a. MPT': every } 6 \text { weeks for six cycles. The } \\
\text { dose of Thalidomide was reduced by } 50 \% \\
\text { on the occurrence of any non-hematologic } \\
\text { grade } 2 \text { toxicity and was discontinued for } \\
\text { any non-hematologic grade } 3 \text { toxicity. } \\
\text { Enoxaparin } 40 \text { mg day was given } \\
\text { subcutaneously during the first } 4 \text { cycles of } \\
\text { therapy, as anticoagulation prophylaxis. } \\
\text { b. MP8: every } 6 \text { weeks. }\end{array}$ & $\begin{array}{l}\text { Response rates, progression-free survival, overall survival, } \\
\text { prognostic factors and adverse events. } \\
\text { Response to treament: Criteria of European Group for Blood and } \\
\text { Marrow Transplantation-Intenational Bone Marrow Transplant } \\
\text { Registry. }\end{array}$ \\
\hline Pavlovsky 1984 & $\begin{array}{l}\text { RCT } \\
N=234 \text { previously } \\
\text { untreated } \\
\text { patients } \text { MP }^{9}=129 \\
\text { MPCVM }^{\prime}=105\end{array}$ & $\begin{array}{l}239 \text { untreated patients with } \\
\text { MM }\end{array}$ & a. MP9 b. MPCVM'1 & $\begin{array}{l}\text { Good response: reduction of }>50 \% \text { in serum M-protein } \\
\text { concentration or }>75 \% \text { in urinary M-protein excretion and } \\
\text { a decrease of }>50 \% \text { in measured cross-sectional area of a } \\
\text { plasmacytoma. } \\
\text { Partial response: decrease of }<50 \% \text { in serum and/or }<75 \% \\
\text { in urinary M-protein with an increase in haemoglobin in the } \\
\text { absence of blood transfusion and performance status. }\end{array}$ \\
\hline
\end{tabular}




\begin{tabular}{|c|c|c|c|c|}
\hline Study & Methods & Participants & Interventions & Outcomes \\
\hline Pönisch 2006 & $\begin{array}{l}\mathrm{RCT} \\
\mathrm{BP}^{\prime}=68 \\
\mathrm{MP}^{10}=63 \\
\\
\text { Randomization was } \\
\text { stratified by the stage of } \\
\text { the disease. }\end{array}$ & $\begin{array}{l}\text { Inclusion criteria: Durie and } \\
\text { Salmon criteria for stage II with } \\
\text { progression or stage III MM, } \\
\text { quantitatively measurable } \\
\text { myeloma proteins in the } \\
\text { serum and/or urine, leukocyte } \\
\text { count }>2,000 / L \text {, platelet } \\
\text { count }>50,000 / L, \text { Karnofsky } \\
\text { performance status of } 60 \%, \\
\text { life expectancy of }>3 \text { months, } \\
\text { no prior chemotherapy or } \\
\text { radiotherapy. } \\
\text { Exclusion criteria: Patients } \\
\text { with nonsecretory and local } \\
\text { plasmacytoma, HIV or Hbs-AG } \\
\text { positivity or active hepatitis, } \\
\text { secondary malignancy, } \\
\text { pregnancy, lactation or } \\
\text { inadequate contraception. }\end{array}$ & $\begin{array}{l}\text { a. } \mathrm{MP}^{10} \\
\text { b. } \mathrm{BP}^{1} \\
\text { Treatment with } \mathrm{MP}^{10} \text { or } \mathrm{BP}^{1} \text { was } \\
\text { administered every } 28 \text { days until maximum } \\
\text { remission or disease progression was } \\
\text { observed. }\end{array}$ & 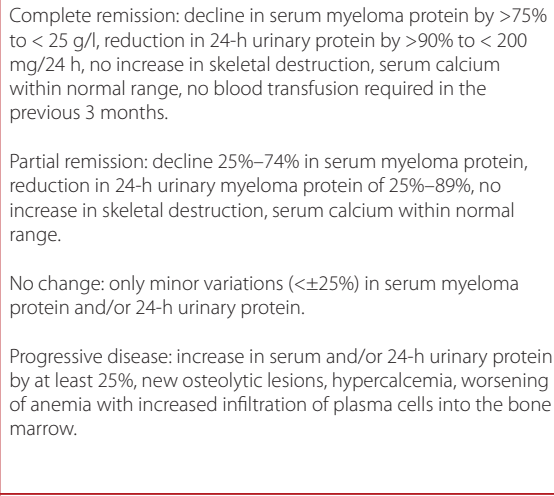 \\
\hline Salmon 1983 & $\begin{array}{l}\text { RCT } \\
N=237 \\
\text { a. VCMP5 and } V^{5} A P^{1} \\
=160 \\
\text { b. } M P^{11}=77\end{array}$ & $\begin{array}{l}\text { Previously untreated patients } \\
\text { with MM. The diagnosis was } \\
\text { established according to criteria } \\
\text { by the Chronic Leukemia- } \\
\text { Myeloma Task Force and the } \\
\text { SWOG. }\end{array}$ & 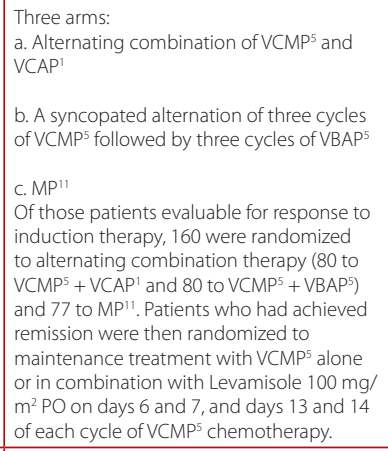 & $\begin{array}{l}\text { SWOG criteria objective remission status: At least a } 75 \% \text { reduction } \\
\text { in the rate of M-component production and tumor burdens, } \\
\text { and improvement in other response criteria (e.g., anemia and } \\
\text { hypercalcaemia). }\end{array}$ \\
\hline San Miguel 2008 & $\begin{array}{l}\text { RCT, multicenter, } \\
\text { open label. } \\
\mathrm{N}=682 \\
\text { MP' plus Bortezomib } \\
=344 \\
\mathrm{MP}^{\mathrm{I}}=338 \\
\text { Randomization was } \\
\text { stratified according to } \\
\text { baseline levels of } \beta 2- \\
\text { microglobulin. }\end{array}$ & $\begin{array}{l}\text { Patients with newly diagnosed, } \\
\text { untreated, symptomatic, } \\
\text { measurable MM who were } \\
\text { not candidates for stem-cell } \\
\text { transplantation because of } \\
\text { age ( } \geq 65 \text { years) or coexisting } \\
\text { conditions were eligible. }\end{array}$ & $\begin{array}{l}\text { a. MP' every } 6 \text { weeks. } \\
\text { b. MP' every } 6 \text { weeks plus Bortezomib } 1.3 \\
\mathrm{mg} / \mathrm{m}^{2}, \text { by intravenous bolus on days } 1, \\
4,8,11,22,25,29, \text { and } 32 \text { during cycles } 1 \\
\text { to } 4 \text { and on days } 1,8,22 \text {, and } 29 \text { during } \\
\text { cycles } 5 \text { to } 9 .\end{array}$ & $\begin{array}{l}\text { Time to disease progression, rate of complete response, duration } \\
\text { of response, time to subsequent myeloma therapy, overall } \\
\text { survival. } \\
\text { Using criteria of the European Group for Blood and Marrow } \\
\text { Transplantation (EBMT). The rate of serious adverse events in the } \\
\text { bortezomib group was higher than that in the control group } \\
(46 \% \text { vs. } 36 \%) \text {. }\end{array}$ \\
\hline Shustik 2006 & $\begin{array}{l}\text { RCT. } \\
\mathrm{N}=466 \\
\mathrm{DEX}=232 \\
\mathrm{MP}^{12}=234 \\
\\
\text { Assessment or mainte- } \\
\text { nance with Desametha- } \\
\text { sone }=292 \\
\text { Observation }=147 \\
\text { Dexamethasone }=145\end{array}$ & $\begin{array}{l}\text { Patients with previously } \\
\text { untreated, symptomatic stage } \\
\text { I or stages II-III MM using the } \\
\text { Salmon-Durie classification. } \\
\\
\text { Inclusion criteria: Histological } \\
\text { confirmation of MM and a } \\
\text { measurable serum monoclonal } \\
\text { paraprotein or urinary } \\
\text { excretion of at least } 1.0 \mathrm{~g} \\
\text { of monoclonal light chain } \\
\text { protein in } 24 \mathrm{~h} \text {. Patients with } \\
\text { marrow plasmacytosis at <10\% } \\
\text { were eligible if a measurable } \\
\text { serum or urine paraprotein } \\
\text { was present with at least one } \\
\text { osteolytic bone lesion. } \\
\\
\text { Exclusion criteria: Comorbid } \\
\text { condition, cancer other than } \\
\text { adequately treated squamous } \\
\text { or basal cell carcinoma of } \\
\text { the skin, carcinoma in situ of } \\
\text { the cervix, or cancer that was } \\
\text { treated more than } 5 \text { years } \\
\text { before study, peptic ulcer } \\
\text { disease. }\end{array}$ & 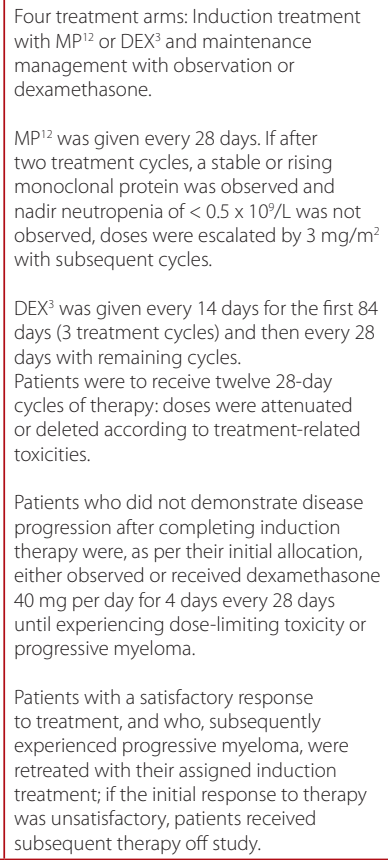 & $\begin{array}{l}\text { Overall survival, response to treatment, progression- free survival, } \\
\text { treatment-related toxicity. } \\
\text { Criteria for response: Reduction in the serum monoclonal } \\
\text { paraprotein by at least } 50 \% \text { and a reduction in the } 24 \text {-h urine } \\
\text { excretion of monoclonal light chain by at least } 90 \% \text {. } \\
\text { Criteria for progressive disease: Increase in the serum monoclonal } \\
\text { paraprotein to least } 50 \% \text { above the baseline value and in the } \\
24 \text {-h urinary monoclonal light chain excretion to }>100 \% \text { above } \\
\text { baseline, hipercalcemia despite chemotherapy, new lytic bone } \\
\text { lesion, progressive cytopenia in conjunction with increasing } \\
\text { marrow plasmacytosis. }\end{array}$ \\
\hline
\end{tabular}




\begin{tabular}{|c|c|c|c|c|}
\hline Study & Methods & Participants & Interventions & Outcomes \\
\hline Tribalto 1985 & $\begin{array}{l}\text { RCT. } \\
N=133 \text { previously un- } \\
\text { treated patient. } N=133 \\
\mathrm{MP}^{13}=47 \\
\mathrm{VCMP}^{6}=53 \\
\mathrm{PCB}^{\prime}=33\end{array}$ & $\begin{array}{l}\text { Only previously untreated } \\
\text { patients with diagnosis of MM } \\
\text { according to the South Western } \\
\text { Oncology Group (SWOG) } \\
\text { criteria. Patients were stratified } \\
\text { according to Durie \& Salmon } \\
\text { System. The presence or abs- } \\
\text { ence of normal renal function } \\
\text { (BUN }<40 \mathrm{mg} \% \text {, creatinine }< \\
2 \mathrm{mg} \% \text { ) subclassified patients } \\
\text { into A and B groups. }\end{array}$ & 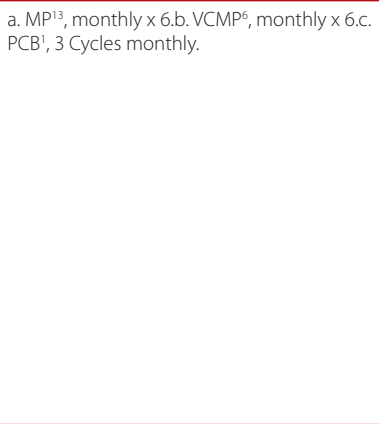 & $\begin{array}{l}\text { Criteria for response by the South Western Oncology Group } \\
\text { (SWOG) criteria: Decrease in the M-proteins of } 75 \% \text { or more, and } \\
\text { to less than } 2,5 \mathrm{~g} / \mathrm{dL} \text {, a }>90 \% \text { decrease in } 24 \text {-h urine globulin, not } \\
\text { increment in size and number of lytic skull lesions, serum calcium } \\
\text { remained normal, correction of anemia and hypoalbuminemia. } \\
\text { Patients with } 50-75 \% \text { decrease in M-protein were considered to } \\
\text { be improved. If not satisfy any of these categories, were deemed } \\
\text { unresponsive. } \\
\text { Progression: Increase in M-protein of at least } 1.0 \mathrm{~g} / \mathrm{dL} \text {, a } \\
100 \% \text { increase in the protein excreted in the urine per } 24 \mathrm{~h} \text {, } \\
\text { hypercalcaemia }>11.0 \mathrm{mg} / \mathrm{dl} \text {, plasmacytomas that enlarge } \\
\text { progressively } \\
\text { Relapse: Rise in M-protein over } 50 \% \text { of the pre-study level, rise in } \\
\text { calcium }>11.0 \mathrm{mg} / \mathrm{dL} \text {, development of plasmacytoma }\end{array}$ \\
\hline Wijermans 2008 & $\begin{array}{l}\text { RCT } \\
N=301 \\
\text { a. } M^{14}=149 \\
\text { b. } \mathrm{MP}^{14} \text { plus Thalidomide } \\
=152\end{array}$ & $\begin{array}{l}\text { Patients with previous } \\
\text { untreated } M M>65 \text { years of age } \\
\text { with a stage } \mathrm{IB} \text { or higher. }\end{array}$ & $\begin{array}{l}\text { a. MP14 every } 4 \text { weeks. } \\
\text { b. MP14 every } 4 \text { weeks plus Thalidomide } \\
200 \text { mg daily. } \\
\text { A maximum of } 8 \text { cycles was planned. In } \\
\text { case of ongoing improvement of response, } \\
\text { further therapy was allowed until a plateau } \\
\text { phase was reached. When a good response } \\
\text { and a plateau phase was reached, the } \\
\text { patients on MP }{ }^{14} \text { plus Thalidomide received } \\
\text { maintenance therapy with Thalidomide } 50 \\
\text { mg/day until disease progression. }\end{array}$ & $\begin{array}{l}\text { Event Free Survival, Progression Free Survival, Overall Survival, } \\
\text { Response Rate. } \\
\text { Responses were assessed using the IMWG criteria. }\end{array}$ \\
\hline Hulin 2009 & $\begin{array}{l}\text { RCT, Multicenter, placebo } \\
\text { study. } \\
\mathrm{N}=229 \\
\begin{array}{l}\text { a. } \mathrm{MP}^{15} \text { plus Placebo } \\
=116 \\
\text { b. } \mathrm{MP}^{15} \text { plus Thalidomide } \\
=113\end{array}\end{array}$ & $\begin{array}{l}\text { Patients had stage II or III, newly } \\
\text { diagnosed MM, according to } \\
\text { Durie-Salmon criteria and were } \\
\text { at least } 75 \text { years of age. Durie- } \\
\text { Salmon stage I MM could be } \\
\text { enrolled if they met the criteria } \\
\text { of high-risk stage I disease. } \\
\text { Exclusion criteria: previous } \\
\text { neoplasms, amyloidosis, a WHO } \\
\text { performance index of } 3 \text { or } \\
\text { higher, renal insufficiency with } \\
\text { creatinine serum concentration } \\
\text { of } 50 \text { mg/L or more; cardiac or } \\
\text { hepatic dysfunction; peripheral } \\
\text { neuropathy; history of venous } \\
\text { thrombosis during the previous } \\
6 \text { months; HIV infection, or } \\
\text { hepatitis B or C infections. }\end{array}$ & $\begin{array}{l}\text { a. MP15 plus Placebo } \\
\text { b. MP15 plus Thalidomide } 100 \mathrm{mg} \\
\text { Placebo or thalidomide was given } \\
\text { continuously for } 72 \text { weeks, administered at } \\
\text { bedtime. A dose reduction to } 50 \mathrm{mg} \text { per } \\
\text { day of Thalidomide or placebo was allowed } \\
\text { at the investigator discretion in the event } \\
\text { of patient intolerance, especially in case of } \\
\text { mild or moderate peripheral neuropathy } \\
\text { (grade } 1 \text { or } 2 \text { ). }\end{array}$ & $\begin{array}{l}\text { Overall survival, safety, response rates, and progression-free } \\
\text { survival. }\end{array}$ \\
\hline
\end{tabular}

RCT: randomized controlled trial; MM: MM; PS: performance status.

MP!: melphalan $9 \mathrm{mg} / \mathrm{m}^{2} \mathrm{PO}$ days $1-4$ + prednisone $60 \mathrm{mg} / \mathrm{m}^{2}$ day PO or IM days 1-4.MP2: melphalan $6 \mathrm{mg} / \mathrm{m}^{2} \mathrm{PO}$ days $1-7+$ prednisone $60 \mathrm{mg} / \mathrm{m}^{2} \mathrm{PO}$ days $1-7$

MP3: melphalan $10 \mathrm{mg} / \mathrm{m}^{2} \mathrm{PO}$ days $1-4+$ prednisone $80 \mathrm{mg} / \mathrm{m}^{2} \mathrm{IM}$ days $1-4$.

MP4: melphalan $16 \mathrm{mg} / \mathrm{m}^{2} \mathrm{PO}$ days $1,15,29,43$, and every 28 days thereafter + 6-week tapering course of prednisone beginning at a dose of $0.8 \mathrm{mg} / \mathrm{kg}$ for 14 days, with reductions to $0.4 \mathrm{mg} / \mathrm{kg}$ days $15-28$, and $0.2 \mathrm{mg} / \mathrm{kg}$ days $29-42$. MP5: melphalan 0,25 mg/kg PO days $1-4+$ prednisone $2 \mathrm{mg} / \mathrm{kg}$ PO days $1-4$

MP: melphalan 0,15 mg/kg PO days $7-7$ every 4 weeks + prednison

MP?: melphalan 0,25 mg/kg PO days $1-4+$ prednisone $100-150 \mathrm{mg}$ dependent of weight PO days $1-4$

days $1-7$ every 4 weeks.

MPP: melphalan $15 \mathrm{mg} / \mathrm{m}^{2}$ in $500 \mathrm{ml} \mathrm{NaCl} 0,9 \%$ infusion over 30 minutes day $1+$ prednisone $60 \mathrm{mg} / \mathrm{m}^{2} \mathrm{PO}$ or IV days $1-4$

MP'1: melphalan $8 \mathrm{mg} / \mathrm{m}^{2}$ PO days $1-4+$ prednisone $60 \mathrm{mg} / \mathrm{m}^{2}$ days $1-4$.

MP'2. melphalan $9 \mathrm{mg} / \mathrm{m}^{2} \mathrm{PO}$ days $1-4+$ prednisone $100 \mathrm{mg} / \mathrm{m}^{2} \mathrm{PO}$ days $1-4$

MP 13 : melphalan $0,1 \mathrm{mg} / \mathrm{kg}$ PO days $1-7+$ prednisone $40 \mathrm{mg} / \mathrm{m}^{2}$

MPi. melphalan $0.25 \mathrm{mg} / \mathrm{kg}$ PO days $1-5+$ prednisone $1 \mathrm{mg} / \mathrm{kg}$ PO days $1-5$.

MP15: melphalan $0,2 \mathrm{mg} / \mathrm{kg}$ PO days $1-4+$ prednisone $2 \mathrm{mg} / \mathrm{kg}$ days $1-4$ every 6 weeks, by 12 cycles

MPT': melphalan $4 \mathrm{mg} / \mathrm{m}^{2} \mathrm{PO}$ days $1-7+$ prednisone $40 \mathrm{mg} / \mathrm{m}^{2} \mathrm{PO}$ days $1-7+$ thalidomide $100 \mathrm{mg} \mathrm{PO}$ continuously at all cycle and as maintenance therapy until evidence of relapse or refractory disease.

MVP': melphalan $0,15 \mathrm{mg} / \mathrm{kg}$ PO day $1+$ vincristine $0,03 \mathrm{mg} / \mathrm{kg}(\max 2 \mathrm{mg})$ IV day 1 ; every week + prednisone

MPCVM!: melphalan $8 \mathrm{mg} / \mathrm{m}^{2} \mathrm{PO}$ days $1-4$ + prednisone $40 \mathrm{mg} / \mathrm{m}^{2} \mathrm{PO}$ days $1-7$ every 4 weeks + Cyclophosphamide $600 \mathrm{mg} / \mathrm{m}^{2} \mathrm{IV}$ day 1 + Vincristine $0,6 \mathrm{mg} / \mathrm{m}^{2} \mathrm{IV}$ day 1 every 4 weeks and MeCCNU $100 \mathrm{mg} / \mathrm{m}^{2} \mathrm{PO}$ day 1 every 8 weeks. BP': Bendamustine $150 \mathrm{mg} / \mathrm{m}^{2}$ in $500 \mathrm{ml} \mathrm{NaCl} 0,9 \%$ infusion over 30 minutes days $1-2+$ prednisone $60 \mathrm{mg} / \mathrm{m}^{2} \mathrm{IV}$ or PO days $1-4$.

VCMP: vincristine $1 \mathrm{mg} I V$ day $1+$ cyclophosphamide $500 \mathrm{mg} / \mathrm{m}^{2} \mathrm{IV}$ day $1+$ melphalan $6 \mathrm{mg} / \mathrm{m}^{2} \mathrm{PO}$ days $1-4$ + prednisone $60 \mathrm{mg} / \mathrm{m}^{2} \mathrm{IV}$ or IM days $1-4$.

VCMP2: vincristine $1 \mathrm{mg} \mathrm{IV} \mathrm{day} 1+$ cyclophosphamide $120 \mathrm{mg} / \mathrm{m}^{2} \mathrm{PO}$ days $1-7+$ melphalan $6 \mathrm{mg} / \mathrm{m}^{2} \mathrm{PO}$ days $1-7+$ prednisone $60 \mathrm{mg} / \mathrm{m}^{2} \mathrm{PO}$ days $1-7$.

VCMP3: vincristine $1 \mathrm{mg} I V$ day $1+$ cyclophosphamide $100 \mathrm{mg} / \mathrm{m}^{2} \mathrm{IV}$ day $14+$ melphalan $5 \mathrm{mg} / \mathrm{m}^{2} \mathrm{PO}$ day $1+$ prednisone $60 \mathrm{mg} / \mathrm{m}^{2} / \mathrm{V}$ day 14 .

VCMP4: vincristine $1 \mathrm{mg} / \mathrm{V}$ day $1+$ cyclophosphamide $100 \mathrm{mg} / \mathrm{m}^{2} \mathrm{PO}$ days $1-4$ + melphalan $5 \mathrm{mg} / \mathrm{m}^{2} \mathrm{PO}$ days $1-4$ + prednisone $60 \mathrm{mg} / \mathrm{m}^{2} \mathrm{PO}$ days $1-3$.

VCMP5: vincristine $1 \mathrm{mg} / \mathrm{m}^{2}$ (maximum $1,5 \mathrm{mg}$ ) IV + cyclophosphamide $125 \mathrm{mg} / \mathrm{m}^{2} \mathrm{PO}$ days $1-4+$ melphalan $6 \mathrm{mg} / \mathrm{m}^{2} \mathrm{PO}$ days $1-4+$ prednisone $60 \mathrm{mg} / \mathrm{m}^{2} \mathrm{PO}$ days $1-4$.

VCMP6: vincristine $1 \mathrm{mg} I V$ day $1+$ ciclosphamide $125 \mathrm{mg} / \mathrm{m}^{2}$ days $1-7+$ melphalan $6 \mathrm{mg} / \mathrm{m}^{2}$ days $1-7+$ prednisone $60 \mathrm{mg} / \mathrm{m}^{2} \mathrm{PO}$ days $1-7$.
VBCMP': melphalan $0,1 \mathrm{mg} / \mathrm{kg}$ PO days $1-7+$ BCNU $0,5 \mathrm{mg} / \mathrm{kg}$ IV day $1+$ cyclophosphamide $10 \mathrm{mg} / \mathrm{kg}$ IV day $1+$ vincristine $0,03 \mathrm{mg} / \mathrm{kg}$ (max $2 \mathrm{mg}$ ) IV day 1 ; every 5 weeks + prednisone

VBAP: vincristine $1 \mathrm{mg} \mathrm{IV} \mathrm{day} 1+$ carmustine $30 \mathrm{mg} / \mathrm{m}^{2} \mathrm{IV}$ day $1+$ doxorubicin $30 \mathrm{mg} / \mathrm{m}^{2} \mathrm{IV}$ day $1+$ prednisone $60 \mathrm{mg} / \mathrm{m}^{2} \mathrm{IV}$ or $\mathrm{IM}$ days $1-4$

VBAP': vincristine $1 \mathrm{mg} I V$ day $1+$ carmustine $30 \mathrm{mg} / \mathrm{m}^{2} \mathrm{IV}$ day $1+$ doxorubicin $30 \mathrm{mg} / \mathrm{m}^{2} \mathrm{IV}$ day $1+$ prednisone $60 \mathrm{mg} / \mathrm{m}^{2} \mathrm{PO}$ days $1-7$

VBAP $P^{3}$ : vincristine $1 \mathrm{mg} I V$ day $1+$ carmustine $30 \mathrm{mg} / \mathrm{m}^{2} \mathrm{IV}$ day $1+$ doxorubicin $30 \mathrm{mg} / \mathrm{m}^{2} \mathrm{IV}$ day $1+$ prednisone $60 \mathrm{mg} / \mathrm{m}^{2} \mathrm{PO}$ days $1-4$

VBAP4: vincristine $1 \mathrm{mg} / \mathrm{V}$ day $1+$ BCNU $30 \mathrm{mg} / \mathrm{m}^{2} \mathrm{IV}$ day $1+$ adriamycin $25 \mathrm{mg} / \mathrm{m}^{2} \mathrm{IV}$ day $1+$ prednisone $60 \mathrm{mg} / \mathrm{m}^{2} \mathrm{PO}$ days $1-4$

VBAP5: vincristine $1 \mathrm{mg} / \mathrm{m}^{2}$ (maximum $1,5 \mathrm{mg}$ ) $\mathrm{V}$ + carmustine $30 \mathrm{mg} / \mathrm{m}^{2} \mathrm{IV}$ day $1+$ doxorubicin $30 \mathrm{mg} / \mathrm{m}^{2} \mathrm{IV}$ day $1+$ prednisone $60 \mathrm{mg} / \mathrm{m}^{2} \mathrm{PO}$ days $1-4$

VCAP': vincristine $1 \mathrm{mg} / \mathrm{m}^{2}$ (maximum $1,5 \mathrm{mg}$ ) IV + cyclophosphamide $125 \mathrm{mg} / \mathrm{m}^{2}$ PO days $1-4+$ doxorubicin $30 \mathrm{mg} / \mathrm{m}^{2} \mathrm{IV}$ day $1+$ prednisone $60 \mathrm{mg} / \mathrm{m}^{2} \mathrm{PO}$ days $1-4$

PCB!: Peptichemio $1 \mathrm{mg} / \mathrm{kg}$ day $1+$ cycophosphamide $15 \mathrm{mg} / \mathrm{kg}$ day $20+$ BCNU $1 \mathrm{mg} / \mathrm{kg}$ day 29.

VCCM! :Vincristine $0,03 \mathrm{mg} / \mathrm{kg}$ IV (max $2 \mathrm{mg}$ ) day $1+$ carmustine (BCNU) 0,5 mg/kg IV on day $1+$ cyclophosphamide $10 \mathrm{mg} / \mathrm{kg}$ IV day $1+$ melphalan 0,25 mg/kg PO days 1-4.

VAD: vincristine $0.4 \mathrm{mg} / \mathrm{m}^{2} \mathrm{IV}$ (continuous infusion) days $1-4+$ doxorubicin $9 \mathrm{mg} / \mathrm{m}^{2} \mathrm{IV}$ (continuous infusion) days $1-4+$ dexamethasone $40 \mathrm{mg}$ PO days $1-4$

VND: vincristine $0.4 \mathrm{mg} / \mathrm{m}^{2} \mathrm{IV}$ (continuous infusion) days $1-4+$ mitoxantrone $3 \mathrm{mg} / \mathrm{m}^{2} \mathrm{IV}$ (continuous infusion) days $1-4+$ dexamethasone $40 \mathrm{mg}$ IV days 1-4.MCBP: melphalan $8 \mathrm{mg} / \mathrm{m}^{2} \mathrm{PO}$ day $1+$ cyclophosphamide $300 \mathrm{mg} / \mathrm{m}^{2} \mathrm{IV}$ day 1 T carmustine $100 \mathrm{mg} / \mathrm{m}^{2} \mathrm{~V}$ day $1+6-$ week tapering course of prednisone $3 \mathrm{mg} / \mathrm{m}$. cyclophosphamide $600 \mathrm{mg} / \mathrm{m}^{2} \mathrm{~V}$ day $22+$ carmustine $150 \mathrm{mg} / \mathrm{m}^{2} \mathrm{~V}$ day $43+6$ - week tapering course of prednisone beginning at a dose of $0.8 \mathrm{mg} / \mathrm{kg}$ for 14 days, with reductions to $0.4 \mathrm{mg} / \mathrm{kg}$ days $15-28$, and $02 \mathrm{mg} / \mathrm{kg}$ days 29.42 . MCBPA melphalan $8 \mathrm{mg} / \mathrm{m}^{2} \mathrm{PO}$ day $1+$ cyclophosphamide $300 \mathrm{mg} / \mathrm{m}^{2} \mathrm{~V}$ day $1+$ carmustine $100 \mathrm{mg} / \mathrm{m}^{2} \mathrm{VV}$ day 1 . Doxorubicin $45 \mathrm{mg} / \mathrm{m}^{2} \mathrm{IV}$ was administered 3 weeks after this therapy in alternate treatment courses (days $85,190.295$. and 400) + 6-week tapering course of prednisone beginning at a dose of $0.8 \mathrm{mg} / \mathrm{kg}$ for 14 days, with reductions to $0.4 \mathrm{mg} / \mathrm{kg}$ days $15-28$, and $0.2 \mathrm{mg} / \mathrm{kg}$ days $29-42$.

DEX': Dexamethasone $40 \mathrm{mg} / \mathrm{d} \mathrm{IV}$ for 4 days beginning on days 1,9 , and 17 by 2 cycles of 6 weeks and $40 \mathrm{mg} / \mathrm{d} \mathrm{IV}$ at day 1 by 10 cycles of 6 weeks.

DEX: melphalan $9 \mathrm{mg} / \mathrm{m} 2 \mathrm{PO}$ days $1-4+$ dexamethasone $20 \mathrm{mg} / \mathrm{m} 2 \mathrm{PO}$ days $1-4$ and $9-12$ every 4 weeks.

DEX: melphalan $9 \mathrm{mg} / \mathrm{m} 2 \mathrm{PO}$ days $1-4+$ dexamethasone $40 \mathrm{mg}$ PO days $1-4$ and $14-15$

$M-D E X^{\prime}: M P^{5}$ and $D E X^{\prime}$ schema at the same time.

DEX-IFN: IFN alfa-2b 3.0 MU SC 3 times weekly + DEX1 schema. The IFN was started with dexamethasone and stopped on day 42 of the last dexamethasone cycle

TD': thalidomide $200 \mathrm{mg}$ PO days 1-4 + dexamethasone $40 \mathrm{mg}$ days $1-4$ 
TRATAMIENTO DE PRIMERA LÍNEA PARA PACIENTES CON MIELOMA MÚLTIPLE NO ELEGIBLES PARA TRASPLANTE AUTÓLOGO

DE CÉLULAS PROGENITORAS: REVISIÓN SISTEMÁTICA Y META-ANÁLISIS (ESTUDIO DEL HEMO-ONCOLGROUP)

Myriam Rodríguez, Juan Felipe Combariza, Claudia Patricia Casas, Ludovic Reveiz, Jefferson Buendía, Arturo Martí-Carvajal, Henry Becerra, Andrés Acevedo, Andrés Felipe Cardona

Annex 2. Assessment of the risk of bias in RCTs included in the review

\begin{tabular}{|c|c|c|c|c|c|c|c|}
\hline Study & $\begin{array}{l}\text { Sequence } \\
\text { generation }\end{array}$ & $\begin{array}{l}\text { Allocation } \\
\text { concealment }\end{array}$ & $\begin{array}{l}\text { Blinding of } \\
\text { participants, } \\
\text { personnel } \\
\text { and outcome } \\
\text { assessors }\end{array}$ & $\begin{array}{l}\text { Incomplete } \\
\text { outcome data } \\
\text { / withdrawals }\end{array}$ & $\begin{array}{l}\text { Free of } \\
\text { selective } \\
\text { reporting }\end{array}$ & $\begin{array}{l}\text { Other sources of bias / } \\
\text { commentaries }\end{array}$ & Overall Risk \\
\hline Blade 1990 & Unclear & Unclear & No & Unclear & Unclear & $\begin{array}{l}\text { A number of patients were not evaluable } \\
\text { for response to therapy. Adverse events } \\
\text { were not reported. }\end{array}$ & Unclear \\
\hline Blade 1993 & Unclear & Unclear & No & Unclear & Unclear & Yes & Unclear \\
\hline Boccadoro 1991 & Unclear & Unclear & No & Unclear & Unclear & $\begin{array}{l}\text { Hematological and non- } \\
\text { hematological adverse events were not } \\
\text { reported. }\end{array}$ & Unclear \\
\hline Cavo 2002 & Unclear & Unclear & No & Unclear & Unclear & Yes & Unclear \\
\hline Cooper 1986 & Unclear & Unclear & No & No & Unclear & Yes & No \\
\hline Facon 2005 & Yes & Unclear & No & Yes & Unclear & Yes & Unclear \\
\hline Facon 2008 & Unclear & Unclear & No & Yes & Unclear & Yes & Unclear \\
\hline Gulbrandsen 2008 (abst.) & Unclear & Unclear & Unclear & Unclear & Unclear & Unclear & Unclear \\
\hline Hamsen 1985 & Yes & Unclear & No & Unclear & Unclear & Yes & Unclear \\
\hline Hernández 2004 & Unclear & Unclear & \begin{tabular}{|l} 
No \\
\end{tabular} & Yes & Unclear & Yes & Unclear \\
\hline HJORT 1990 & Unclear & Unclear & No & Unclear & Unclear & Yes & Unclear \\
\hline Hulin 2009 & Unclear & Yes & Unclear & Yes & Unclear & $\begin{array}{l}\text { Baseline characteristics were well balanced } \\
\text { except for gender. }\end{array}$ & Unclear \\
\hline Kildahl-Andersen 1988 & Unclear & Unclear & No & Unclear & Unclear & Adverse events were not reported. & Unclear \\
\hline Ludwig 2008 & Yes & Yes & No & Yes & Unclear & Yes & Yes \\
\hline Osterborg 1989 & Unclear & Unclear & No & Unclear & Unclear & Yes & Unclear \\
\hline Palumbo 2006 & Yes & Yes & No & Unclear & Unclear & $\begin{array}{l}\text { Hematological and non- } \\
\text { hematological adverse events were not } \\
\text { reported for each group. }\end{array}$ & Yes \\
\hline \begin{tabular}{|l|} 
Pavlovsky 1984 \\
\end{tabular} & Unclear & Unclear & No & Unclear & Unclear & No sample size calculation. & Unclear \\
\hline Pönisch 2006 & Unclear & Unclear & No & Yes & Unclear & $\begin{array}{l}\text { Every adverse event was reported (i.e. } \\
\text { leukopenia, anemia, thrombocytopenia), } \\
\text { however they were not be summarized as } \\
\text { "hematological toxicity". }\end{array}$ & Unclear \\
\hline Salmon 1983 & Unclear & Unclear & No & Unclear & Unclear & Yes & Unclear \\
\hline San Miguel 2008 & Unclear & Unclear & No & Unclear & Unclear & $\begin{array}{l}\text { Every adverse event was reported, however } \\
\text { they were not be summarized as "hemato- } \\
\text { logical toxicity". }\end{array}$ & Unclear \\
\hline Shustik 2006 & Yes & Yes & No & Yes & Unclear & Yes & Yes \\
\hline Tribalto 1985 & Yes & Unclear & No & No & Unclear & $\begin{array}{l}\text { Hematological and non- } \\
\text { hematological adverse events were not } \\
\text { adequately reported. }\end{array}$ & Unclear \\
\hline Wijermans 2008 (abst.) & Unclear & Unclear & No & Unclear & Unclear & Unclear & Unclear \\
\hline
\end{tabular}

Abst:: abstract.

Annex 3. Funnel plot

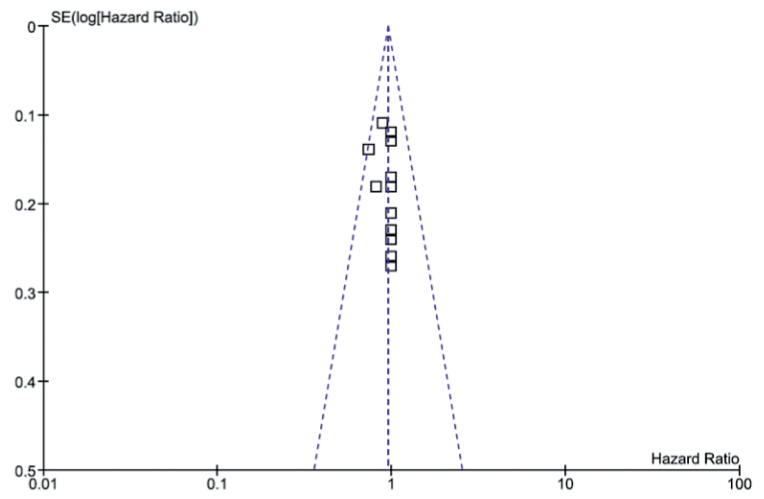




\section{References}

1. Bergsagel DE, Bergsagel PL. Epidemiology and etiology of plasma cell neoplasms. In: Gahrton G, Durie BGM, Samson DM, editors. Multiple myeloma and related disorders. London: Arnold; 2004:15-45.

2. Devesa SS. Descriptive epidemiology of multiple myeloma. In: Obrams Gl, Potter $\mathrm{M}$, editors. Epidemiology and biology of multiple myeloma. Berlin: Springer-Verlag; 1991:3-12.

3. International Myeloma Working Group. Criteria for the classification of monoclonal gammopathies, multiple myeloma and related disorders: a report of the International Myeloma Working Group. Br J Haematol. 2003;121(5):749-57.

4. Kyle RA, Rajkumar SV. Multiple myeloma. N Engl J Med. 2004;351(18):1860-73.

5. Greenlee RT, Murray T, Bolden S, Wingo PA. Cancer statistics, 2000. Cancer J Clin. 2000:50:7-33.

6. Jantunen E, Kuittinen T, Penttilä K, Lehtonen P, Mahlamäki E, Nousiainen T. High-dose melphalan $\left(200 \mathrm{mg} / \mathrm{m}^{2}\right)$ supported by autologous stem cell transplantation is safe and effective in elderly (> or $=65$ years) myeloma patients: comparison with younger patients treated on the same protocol. Bone Marrow Transplant. 2006;37:917-22.

7. Gertz MA, Lacy MQ, Dispenzieri A, Greipp PR, Litzow MR, Henderson KJ, et al. Clinical implications of t(11;14)(q13;q32), $\mathrm{t}(4 ; 14)(\mathrm{p} 16.3 ; \mathrm{q} 32)$, and $-17 \mathrm{p} 13$ in myeloma patients treated with high-dose therapy. Blood. 2005; 106:2837-40.

8. Terpos E, Eleutherakis-Papaiakovou V, Dimopoulos MA. Clinical implications of chromosomal abnormalities in multiple myeloma. Leuk Lymphoma. 2006;47(5):803-14.

9. Myeloma Trialists' Collaborative Group. Combination chemotherapy versus melphalan plus prednisone as treatment for multiple myeloma: an overview of 6,633 patients from 27 randomized trials. J Clin Oncol. 1998;16:3832-42.

10. Facon T, Mary JY, Pégourie B, Attal M, Renaud M, Sadoun A, et al. Intergroupe Francophone du Myélome (IFM) group. Dexamethasone-based regimens versus melphalan-prednisone for elderly multiple myeloma patients ineligible for highdose therapy. Blood. 2006;107:1292-8.

11. Rajkumar SV, Hayman S, Gertz MA, Dispenzieri A, Lacy MQ, Greipp PR, et al. Combination therapy with thalidomide plus dexamethasone for newly diagnosed myeloma. J Clin Oncol. 2002;20:4319-23

12. Weber D, Rankin K, Gavino M, Delasalle K, Alexanian R. Thalidomide alone or with dexamethasone for previously untreated multiple myeloma. J Clin Oncol. 2003;21:16-9.

13. Palumbo A, Bringhen S, Caravita T, Merla E, Capparella V, Callea $V$, et al. Oral melphalan and prednisone chemotherapy plus thalidomide compared with melphalan and prednisone alone in elderly patients with multiple myeloma: randomised controlled trial. Lancet. 2006;367(9513):825-31.

14. Palumbo A, Bringhen S, Liberati AM, Caravita T, Falcone A, Callea $V$, et al. Oral melphalan, prednisone, and thalidomide in elderly patients with multiple myeloma: updated results of a randomized controlled trial. Blood 2008;112(8):3107-14.

15. Hideshima T, Richardson P, Chauhan D, Palombella VJ, Elliott PJ, Adams J, et al. The proteasome inhibitor PS-341 inhibits growth, induces apoptosis, and overcomes drug resistance in human multiple myeloma cells. Cancer Res. 2001:61:3071-6.
16. Ma MH, Yang HH, Parker K, Manyak S, Friedman JM, Altamirano $C$, et al. The proteasome inhibitor PS-341 markedly enhances sensitivity of multiple myeloma tumor cells to chemotherapeutic agents. Clin Cancer Res. 2003;9:1136-44.

17. Moreau P, Hulin C, Facon T. Frontline treatment of multiple myeloma in elderly patients. Blood Rev. 2008;22(6):303-9.

18. San Miguel JF, Schlag R, Khuageva NK, Dimopoulos MA, Shpilberg O, Kropff M, et al; VISTA Trial Investigators. Bortezomib plus melphalan and prednisone for initial treatment of multiple myeloma. N Engl J Med. 2008;359(9):906-17.

19. Kyle RA, Rajkumar SV. Criteria for diagnosis, staging, risk stratification and response assessment of multiple myeloma. Leukemia. 2009;23(1):3-9.

20. Golder S, McIntosh HM, Duffy S, Glanville J. Centre for Reviews and Dissemination and UK Cochrane Centre Search Filters Design Group. Developing efficient search strategies to identify reports of adverse effects in Medline and Embase. Health Inf Lib J. 2006;23(1):3-12.

21. Higgins JPT, Green S (editors). Cochrane Handbook for Systematic Reviews of Interventions Version 5.0.0 [updated February 2008].. In: The Cochrane Collaboration, 2008. Available from <www.cochrane-handbook.orgs. The Cochrane Collaboration, 2008.

22. Tierney JF, Stewart LA, Ghersi D, Burdett S, Sydes MR. Practical methods for incorporating summary time-to-event data into meta-analysis. Trials. 2007;7;8:16.

23. Bladé J, San Miguel J, Alcalá A, Maldonado J, García-Conde J, Moro MJ, et al. A randomized multicentric study comparing alternating combination chemotherapy (VCMPNBAP) and melphalan-prednisone in multiple myeloma. Blut. 1990;60(6):319-22

24. Bladé J, San Miguel JF, Alcalá A, Maldonado J, Sanz MA, García-Conde J, et al. Alternating combination VCMPNBAP chemotherapy versus melphalan/prednisone in the treatment of multiple myeloma: a randomized multicentric study of 487 patients. J Clin Oncol. 1993;11(6):1165-71.

25. Boccadoro M, Marmont F, Tribalto M, Avvisati G, Andriani A, Barbui $T$, et al. Multiple myeloma: VMCPNBAP alternating combination chemotherapy is not superior to melphalan and prednisone even in high-risk patients. J Clin Oncol. 1991;9(3):444-8.

26. Cavo M, Benni M, Ronconi S, Fiacchini M, Gozzetti A, Zamagni $\mathrm{E}$, et al; Writing Committee of the "Bologna 90" Clinical Trial. Melphalan-prednisone versus alternating combination VAD/MP or VND/MP as primary therapy for multiple myeloma: final analysis of a randomized clinical study. Haematologica. 2002;87 (9):934-42.

27. Cooper MR, McIntyre OR, Propert KJ, Kochwa S, Anderson K, Coleman $\mathrm{M}$, et al. Single, sequential, and multiple alkylating agent therapy for multiple myeloma: a CALGB Study. J Clin Oncol. 1986;4(9):1331-9.

28. Facon $T$, Mary JY, Hulin $C$, Benboubker $L$, Attal M, Pegourie $B$, et al; Intergroupe Francophone du Myélome. Melphalan and prednisone plus thalidomide versus melphalan and prednisone alone or reduced-intensity autologous stem cell transplantation in elderly patients with multiple myeloma (IFM 99-06): a randomised trial. Lancet. 2007;370:1209-18 
29. Facon T, Mary JY, Pégourie B, Attal M, Renaud M, Sadoun A, et al; Intergroupe Francophone du Myélome (IFM) group. Dexamethasone-based regimens versus melphalan-prednisone for elderly multiple myeloma patients ineligible for highdose therapy. Blood. 2006;107(4):1292-8.

30. Hansen OP, Clausen NA, Drivsholm A, Laursen B. Phase III study of intermittent 5-drug regimen (VBCMP) versus intermittent 3-drug regimen (VMP) versus intermittent melphalan and prednisone (MP) in myelomatosis. Scand J Haematol. 1985;35(5):518-24.

31. Hernández JM, García-Sanz R, Golvano E, Bladé J, Fernández-Calvo J, Trujillo J, et al. Randomized comparison of dexamethasone combined with melphalan versus melphalan with prednisone in the treatment of elderly patients with multiple myeloma. Br J Haematol. 2004;127(2):159-64.

32. Hjorth M, Hellquist L, Holmberg E, Magnusson B, Rödjer S, Westin J. Initial treatment in multiple myeloma: no advantage of multidrug chemotherapy over melphalan-prednisone. The Myeloma Group of Western Sweden. Br J Haematol. 1990;74(2):185-91.

33. Kildahl-Andersen O, Bjark P, Bondevik A, Bull O, Burgess G, Dehli $O$, et al. Multiple myeloma in central and northern Norway 1981-1982: a follow-up study of a randomized clinical trial of 5-drug combination therapy versus standard therapy. Eur J Haematol. 1988;41(1):47-51.

34. Ludwig H, Hajek R, Tóthová E, Drach J, Adam Z, Labar B, et al. Thalidomide-dexamethasone compared to melphalan-prednisolone in elderly patients with multiple myeloma. Blood. 2009;113(15):3435-42.

35. Osterborg A, Ahre A, Björkholm M, Björeman M, Brenning G, Gahrton $G$, et al. Oral versus intravenous melphalan and prednisone treatment in multiple myeloma stage II. A randomized study from the Myeloma Group of Central Sweden. Acta Oncol. 1990;29(6):727-31.

36. Pavlovsky S, Saslavsky J, Tezanos Pinto M, Palmer L, Curuchet $\mathrm{M}$, et al. A randomized trial of melphalan and prednisone versus melphalan, prednisone, cyclophosphamide, MeCCNU, and vincristine in untreated multiple myeloma. J Clin Oncol. 1984;2(7):836-40.

37. Pönisch W, Mitrou PS, Merkle K, Herold M, Assmann M, Wilhelm G, et al; East German Study Group of Hematology and Oncology (OSHO). Treatment of bendamustine and prednisone in patients with newly diagnosed multiple myeloma results in superior complete response rate, prolonged time to treatment failure and improved quality of life compared to treatment with melphalan and prednisone--a randomized phase III study of the East German Study Group of Hematology and Oncology (OSHO). J Can Res Clin Oncol. 2006;132(4):205-12.

38. Salmon SE, Haut A, Bonnet JD, Amare M, Weick JK, Durie BG, et al. Alternating combination chemotherapy and levamisole improves survival in multiple myeloma: a Southwest Oncology Group Study. J Clin Oncol. 1983;1(8):453-61.

39. Shustik $C$, Belch A, Robinson S, Rubin SH, Dolan SP, Kovacs $\mathrm{MJ}$, et al. A randomised comparison of melphalan with prednisone or dexamethasone as induction therapy and dexamethasone or observation as maintenance therapy in multiple myeloma: NCIC CTG MY.7. Br J Haematol. 2007;136(2):203-11.

40. Tribalto M, Amadori S, Cantonetti M, Franchi A, Papa G, Pileri $A$, et al. Treatment of multiple myeloma: a randomized study of three different regimens. Leuk Res. 1985;9(8):1043-9.
41. Wijermans $P$, Schaafsma $M$, van Norden $Y$, Ammerlaan $R$, Wittebol $S$, Sinnige $H$, et al. Melphalan + prednisone versus melphalan + prednisone + thalidomide in induction therapy for multiple myeloma in elderly patients: final analysis of the Dutch Cooperative Group HOVON 49 study. Program and abstracts of the 50th American Society of Hematology Annual Meeting and Exposition; December 6-9, 2008; San Francisco, California. Abstract 649.

42. Gulbrandsen N, Waage A, Gimsing $P$, et al. A randomised placebo controlled study with melphalan/prednisone vs melphalan/prednisone/thalidomide: quality of life and toxicity. 13th Congress of the European Hematology Association, June 1215, 2008.

43. San Miguel JF, Schlag R, Khuageva NK, et al. Updated followup and results of subsequent therapy in the phase III VISTA trial: bortezomib plus melphalan-prednisone versus melphalanprednisone in newly diagnosed multiple myeloma. Program and abstracts of the 50th American Society of Hematology Annual Meeting and Exposition; December 6-9, 2008; San Francisco, California. Abstract 650.

44. Hulin C, Facon T, Rodon P, Pegourie B, Benboubker L, Doyen C, et al. Efficacy of melphalan and prednisone plus thalidomide in patients older than 75 years with newly diagnosed multiple myeloma: IFM 01/01 trial. J Clin Oncol. 2009;27(22):3664-70.

45. Alexanian R, Haut A, Khan AU, Lane M, McKelvey EM, Migliore PJ, et al. Treatment for multiple myeloma. Combination chemotherapy with different melphalan dose regimens. JAMA. 1969;208(9):1680-5.

46. Ahre A, Björkholm M, Mellstedt $H$, Holm G, Brenning G, Engstedt $L$, et al. Intermittent high-dose melphalan/prednisone vs continuous low-dose melphalan treatment in multiple myeloma. Eur J Can Clin Oncol. 1983;19(4):499-506.

47. Attal M, Harousseau JL, Leyvraz S, Doyen C, Hulin C, Benboubker L, et al; Inter-Groupe Francophone du Myélome (IFM). Maintenance therapy with thalidomide improves survival in patients with multiple myeloma. Blood. 2006;108(10):3289-94.

48. Avilés A, Nambo MJ, Neri N, Castañeda C, Cleto S, HuertaGuzmán J. Antitumor effect of zoledronic acid in previously untreated patients with multiple myeloma. Med Oncol. 2007;24(2):227-30

49. Bladé J, Muñoz M, Fontanillas M, San Miguel J, Alcalá A, Maldonado J, et al. Treatment of multiple myeloma in elderly people: long-term results in 178 patients. Age Ageing. 1996;25(5):357-61

50. Bladé J, Rosiñol L, Sureda A, Ribera JM, Díaz-Mediavilla J, García-Laraña J, et al; Programa para el Estudio de la Terapéutica en Hemopatía Maligna (PETHEMA). High-dose therapy intensification compared with continued standard chemotherapy in multiple myeloma patients responding to the initial chemotherapy: long-term results from a prospective randomized trial from the Spanish cooperative group PETHEMA. Blood. 2005;106(12):3755-9.

51. Bladé J, San Miguel JF, Fontanillas M, Esteve J, Maldonado J, Alcalá A, et al. Increased conventional chemotherapy does not improve survival in multiple myeloma: long-term results of two PETHEMA trials including 914 patients. Hematol J. $2001 ; 2(4): 272-8$.

52. Breitkreutz I, Raab MS, Vallet S, Hideshima T, Raje N, Mitsiades $C$, et al. Lenalidomide inhibits osteoclastogenesis, survival factors and bone-remodeling markers in multiple myeloma. Leukemia. 2008;22(10):1925-32. 
53. Clavio M, Casciaro S, Gatti AM, Spriano M, Bonanni F, Poggi $A$, et al . Multiple myeloma in the elderly: clinical features and response to treatment in 113 patients. Haematologica. 1996;81(3):238-44.

54. Cohen HJ, Bartolucci A. Age and the treatment of multiple myeloma. Southeastern Cancer Study Group experience. Am J Med. 1985;79(3):316-24

55. Cohen HJ, Silberman HR, Tornyos K, Bartolucci AA. Comparison of two long-term chemotherapy regimens, with or without agents to modify skeletal repair, in multiple myeloma. Blood. 1984;63(3):639-48

56. Cooper MR, McIntyre OR, Propert KJ, Kochwa S, Anderson K, Coleman $\mathrm{M}$, et al. Single, sequential, and multiple alkylating agent therapy for multiple myeloma: a CALGB Study. J Clin Oncol. 1986;4(9):1331-9.

57. Cornwell GG 3rd, Pajak TF, Kochwa S, McIntyre OR, Glowienka LP, Brunner K, et al. Vincristine and prednisone prolong the survival of patients receiving intravenous or oral melphalan for multiple myeloma: Cancer and Leukemia Group B experience. J Clin Oncol. 1988;6(9):1481-90.

58. Cornwell GG, Pajak TF, Kochwa S, McIntyre OR, Glowienka LP, Brunner K, et al. Comparison of oral melphalan, CCNU, and $\mathrm{BCNU}$ with and without vincristine and prednisone in the treatment of multiple myeloma. Cancer and Leukemia Group B experience. Cancer. 1982;50(9):1669-75

59. Dimopoulos MA, Kastritis E. Thalidomide plus dexamethasone as primary therapy for newly diagnosed patients with multiple myeloma. Nat Clin Pract Oncol. 2008;5(12):690-1.

60. Dimopoulos MA, Pouli A, Zervas K, Grigoraki V, Symeonidis A, Repoussis P, et al; Greek Myeloma Study Group. Prospective randomized comparison of vincristine, doxorubicin and dexamethasone (VAD) administered as intravenous bolus injection and VAD with liposomal doxorubicin as first-line treatment in multiple myeloma. Ann Oncol. 2003;14(7):1039-44.

61. Dulley FL, Saboya R, Hungria VT, Bueno ND, Mello FG, Frota $M T$, et al. Liposomal daunorubicin and dexamethasone as a treatment for multiple myeloma: the DD Protocol. São Paulo Med J. 2005;123(6):266-70.

62. Durie BG. Chemotherapy of myeloma: Southwest Oncology Group studies. Hematol Oncol. 1988;6(2):141-4.

63. Facon T, Mary JY, Hulin C, Benboubker L, Attal M, Pegourie $B$, et al. Melphalan and prednisone plus thalidomide versus melphalan and prednisone alone or reduced-intensity autologous stem cell transplantation in elderly patients with multiple myeloma (IFM 99-06): a randomised trial. Lancet. 2007;370(9594):1209-18.

64. Facon T, Mary JY, Pégourie B, Attal M, Renaud M, Sadoun $A$, et al.; on behalf of the Intergroupe Francophone du Myélome (IFM) group. Dexamethasone-based regimens versus melphalan-prednisone for elderly multiple myeloma patients ineligible for high-dose therapy. Blood. 2006;107(4):1292-8.

65. Facon T, Harousseau MJ, et al.; on behalf of the Intergroupe Francophone du Myélome. Superiority of melphalan-prednisone ( $\mathrm{mp}$ ) + thalidomide (thal) over $\mathrm{mp}$ and autologous stem cell transplantation in the treatment of newly diagnosed elderly patients with multiple myeloma. J Clin Oncol. 2006;24(pt 1 suppl 18S):1s.

66. Fonseca R, Rajkumar SV. Consolidation therapy with bortezomib/lenalidomide/ dexamethasone versus bortezomib/dexamethasone after a dexamethasone-based induction regimen in patients with multiple myeloma: a randomized phase III trial. Clin Lymph Myel. 2008;8(5):315-7.

67. Goldschmidt H, Sonneveld P, Cremer FW, van der Holt B, Westveer $\mathrm{P}$, Breitkreutz I, et al; HOVON; GMMG Joint HOVON-50/ GMMG-HD3 randomized trial on the effect of thalidomide as part of a high-dose therapy regimen and as maintenance treatment for newly diagnosed myeloma patients. Ann Hematol. 2003;82(10):654-9.

68. Greipp PR. Eastern Cooperative Oncology Group E1A00: phase III randomized study of dexamethasone with or without thalidomide in patients with newly diagnosed multiple myeloma. Clin Adv Hematol Oncol. 2003;1(3):188-9.

69. Hansen OP, Clausen NA, Drivsholm A, Laursen B. Phase III study of intermittent 5-drug regimen (VBCMP) versus intermittent 3-drug regimen (VMP) versus intermittent melphalan and prednisone (MP) in myelomatosis. Scand J Haematol. 1985;35(5):518-24

70. Hazarika M, Rock E, Williams G, Dagher R, Sridhara R, Booth $B$, et al. Lenalidomide in combination with dexamethasone for the treatment of multiple myeloma after one prior therapy. Oncologist. 2008;13(10):1120-7.

71. Hernández-Martín JM, Golvano E, García-Sanz R, Mateo G, Trujillo J, Fdez-Calvo FJ, et al. Melphalan/prednisone vs. melphalan/dexamethasone as first line treatment in elderly multiple myeloma patients [abstract]. Hematology Journal 2003; 4 (Suppl 1) S189. Multiple Myeloma, 9th International Workshop, Salamanca, Spain, May 23-27, 2003 [Abstract NO: 227].

72. Hjorth M, Hellquist L, Holmberg E, Magnusson B, Rödjer S, Westin J. Initial versus deferred melphalan-prednisone therapy for asymptomatic multiple myeloma stage l--a randomized study. Myeloma Group of Western Sweden. Eur J Haematol. 1993;50(2):95-102.

73. Hulin C, Facon T, Rodon P. Melphalan-prednisone-thalidomide (MP-T) demonstrates a significant survival advantage in elderly patients 75 years with multiple myeloma compared with melphalan-prednisone (MP) in a randomized, double-blind, placebo-controlled trial, IFM 01/01. Blood. 2007;110:11a.

74. Hulin C, Virion J, Leleu X, Rodon P, Pegourie B, Benboubker $L$, et al; Intergroupe Francophone du Myélome. Comparison of melphalan-prednisone-thalidomide (MP-T) to melphalanprednisone (MP) in patients 75 years of age or older with untreated multiple myeloma (MM). Preliminary results of the randomized, double-blind, placebo controlled IFM 01-01 trial. J Clin Oncol. 2007;25(18S):8001.

75. Jagannath $S$, Durie BGM, Wolf JL, Camacho ES, Irwin D, Lutzky J, et al. Long-term follow-up of patients treated with bortezomib alone and in combination with dexamethasone as frontline therapy for multiple myeloma. Blood. 2006; 108(11 Part 1):238-9.

76. Kildahl-Andersen $O$, Bjark P, Bondevik A, Bull O, Burgess G, Dehli $O$, et al. Multiple myeloma in central and northern Norway 1981-1982: a follow-up study of a randomized clinical trial of 5-drug combination therapy versus standard therapy. Eur J Haematol. 1988;41(1):47-51.

77. Kildahl-Andersen O, Bjark P, Bondevik A, Bull O, Dehli O, Kvambe $\mathrm{V}$, et al. Multiple myeloma in central Norway 1981-1982: a randomized clinical trial of 5-drug combination therapy versus standard therapy. Scand J Haematol. 1986;37(3):243-8.

78. Kyle RA, Leong T, Li S, Oken MM, Kay NE, Van Ness B, et al. Complete response in multiple myeloma: clinical trial E9486, 
an Eastern Cooperative Oncology Group study not involving stem cell transplantation. Cancer. 2006;106(9):1958-66.

79. Lee ML, Chang M, Whitmore GA. A threshold regression mixture model for assessing treatment efficacy in a multiple myeloma clinical trial. J Biopharm Stat. 2008;18(6):1136-49.

80. Lenalidomide and melphalan in treating patients with previously untreated multiple myeloma. Clinicaltrials.gov Identifier: NCT00305812. URL: <http://www.clinicaltrials.gov/> accessed: June 2009.

81. Lokhorst HM, Schmidt-Wolf I, Sonneveld P, van der Holt B, Martin H, Barge R, et al; Dutch-Belgian HOVON; German GMMG Thalidomide in induction treatment increases the very good partial response rate before and after high-dose therapy in previously untreated multiple myeloma. Haematologica. 2008;93(1):124-7.

82. Ludwig $H$, Spicka I, Klener P, Greil R, Adam Z, Gisslinger $H$, et al. Continuous prednisolone versus conventional prednisolone with VMCP-interferon-alpha2b as first-line chemotherapy in elderly patients with multiple myeloma. $\mathrm{Br} J$ Haematol. 2005; 131(3):329-37.

83. Ludwig H, Tothova E, Hajek R, Drach J, Adam Z, Labar B, et al. Thalidomide-dexamethasone vs. melphalan-prednisone as first line treatment and thalidomide-interferon vs. interferon maintenance therapy in elderly patients with multiple myeloma. Blood. 2007;110(11):163a.

84. Ludwig H, Tothova E, Hajek R, Drach J, Labar B, Egyed M, et al. Thalidomide-dexamethasone versus melphalan-prednisolone as first line treatment in elderly patients with multiple myeloma: a second interim analysis. Haematologica. 2007; 92(Suppl 1):166.

85. Ludwig HL, Drach J, Tothova E, Gisslinger H, Linkesch W, Jaksic $B$, et al. Thalidomide-dexamethasone versus melphalan-prednisolone as first line treatment in elderly patients with multiple myeloma: an interim analysis. Haematologica. 2005;90(Suppl 2):158.

86. Mateos MV, Hernández JM, Hernández MT, Gutiérrez NC, Palomera L, Fuertes $\mathrm{M}$, et al. Bortezomib plus melphalan and prednisone in elderly untreated patients with multiple myeloma: updated time-to-events results and prognostic factors for time to progression. Haematologica. 2008;93(4):560-5.

87. Monconduit M, Menard JF, Michaux JL, Le Loet X, Bernard $J F$, Grosbois $B$, et al. VAD or VMBCP in severe multiple myeloma. The Groupe d'Etudes et de Recherche sur le Myélome (GERM). Br J Haematol. 1992;80(2):199-204.

88. Musto P, Falcone A, Sanpaolo G, Bodenizza C, Cascavilla N, Melillo $L$, et al. Pamidronate reduces skeletal events but does not improve progression-free survival in early-stage untreated myeloma: results of a randomized trial. Leuk Lymphoma. 2003;44(9):1545-8

89. Musto P, Petrucci MT, Bringhen S, Guglielmelli T, Caravita T, Bongarzoni V, et al; GIMEMA (Italian Group for Adult Hematologic Diseases)/Multiple Myeloma Working Party and the Italian Myeloma Network. A multicenter, randomized clinical trial comparing zoledronic acid versus observation in patients with asymptomatic myeloma. Cancer. 2008;113(7):1588-95.

90. Myeloma Trialists' Collaborative Group. Combination chemotherapy versus melphalan plus prednisone as treatment for multiple myeloma: an overview of 6,633 patients from 27 randomized trials. J Clin Oncol. 1998;16(12):3832-42.

91. Nagura E, Ichikawa A, Kamiya O, Kato R, Utsumi M, Tanaka $\mathrm{M}$, et al. A randomized study comparing VMCP and MMPP in the treatment of multiple myeloma. Cancer Chemother Pharmacol. 1997;39(4):279-85

92. Niesvizky R, Jayabalan DS, Christos PJ, Furst JR, Naib T, Ely $S$, et al. BiRD (Biaxin [clarithromycin]/Revlimid [lenalidomide]/ dexamethasone) combination therapy results in high complete- and overall-response rates in treatment-naive symptomatic multiple myeloma. Blood. 2008;111(3):1101-9.

93. Niesvizky R, Richardson PG, Rajkumar SV, Coleman M, Rosiñol $L$, Sonneveld $P$, et al. The relationship between quality of response and clinical benefit for patients treated on the bortezomib arm of the international, randomized, phase 3 APEX trial in relapsed multiple myeloma. $\mathrm{Br} J$ Haematol. 2008;143(1):46-53.

94. Oken MM, Harrington DP, Abramson N, Kyle RA, Knospe W, Glick JH. Comparison of melphalan and prednisone with vincristine, carmustine, melphalan, cyclophosphamide, and prednisone in the treatment of multiple myeloma: results of Eastern Cooperative Oncology Group Study E2479. Cancer. 1997;79(8):1561-7

95. Oken MM, Leong T, Lenhard RE Jr, Greipp PR, Kay NE, Van Ness $B$, et al. The addition of interferon or high dose cyclophosphamide to standard chemotherapy in the treatment of patients with multiple myeloma: phase III Eastern Cooperative Oncology Group Clinical Trial EST 9486. Cancer. 1999;86(6):957-68.

96. Oken MM, Leong T, Lenhard RE, Greipp PR, Kay NE, Van Ness $B$, et al. The addition of interferon or high dose cyclophosphamide to standard chemotherapy in the treatment of patients with multiple myeloma: phase III Eastern Cooperative Oncology Group Clinical Trial EST 9486. Cancer. 1999;86(6):957-68.

97. Osterborg A, Ahre A, Björkholm M, Björeman M, Brenning G, Gahrton $G$, et al. Oral versus intravenous melphalan and prednisone treatment in multiple myeloma stage II. A randomized study from the Myeloma Group of Central Sweden. Acta Oncol. 1990;29(6):727-31

98. Palumbo A, Boccadoro M. A new standard of care for elderly patients with myeloma. Lancet. 2007;370(9594):1191-2.

99. Palumbo A, Bringhen S, Petrucci MT, Musto P, Rossini F, Nunzi $M$, et al. Intermediate-dose melphalan improves survival of myeloma patients aged 50 to 70: results of a randomized controlled trial. Blood. 2004;104(10):3052-7.

100. Palumbo A, Falco P, Corradini P, Falcone A, Di Raimondo F, Giuliani N, et al. Melphalan, prednisone, and lenalidomide Treatment for newly diagnosed myeloma: a report from the GIMEMA-Italian Multiple Myeloma Network. J Clin Oncol 2007;25(28):4459-65.

101. Palva IP, Ahrenberg $P$, Ala-Harja $K$, Almqvist $A$, Apajalahti J, Hallman $\mathrm{H}$, et al. Treatment of multiple myeloma with an intensive 5-drug combination or intermittent melphalan and prednisone; a randomised multicentre trial. Finnish Leukaemia Group. Eur J Haematol. 1987;38(1):50-4.

102. Palva IP, Ahrenberg P, Ala-Harja K, Almqvist A, Hänninen A, IIvonen $\mathrm{M}$, et al. Treatment of multiple myeloma in old patients. Finnish Leukaemia Group. Eur J Haematol. 1989;43(4):32831.

103. Palva IP, Ala-Harja K, Almqvist A, Elonen E, Hallman H, Hänninen $\mathrm{A}$, et al. Corticosteroid is not beneficial in multiple-drug combination chemotherapy for multiple myeloma. Finnish Leukaemia Group. Eur J Haematol. 1993;51(2):98-101.

104. Pavlovsky S, Corrado C, Santarelli MT, Saslavsky J, Cavagnaro F, Palau M, et al. An update of two randomized trials in previ- 
ously untreated multiple myeloma comparing melphalan and prednisone versus three- and five-drug combinations: an Argentine Group for the Treatment of Acute Leukemia Study. J Clin Oncol. 1988;6(5):769-75.

105. Peest D, Deicher H, Coldewey R, Leo R, Bartl R, Bartels $H$, et al. Melphalan and prednisone (MP) versus vincristine, BCNU, adriamycin, melphalan and dexamethasone (VBAM Dex) induction chemotherapy and interferon maintenance treatment in multiple myeloma. Current results of a multicenter trial. The German Myeloma Treatment Group. Onkologie. 1990;13(6):458-60

106. Peest $D$, Deicher $H$, Coldewey $R$, von Broen IM, Cammerer $U$, Hein R, et al. Melphalan and prednisone (MP) versus vincristine, $\mathrm{BCNU}$, adriamycin, melphalan and dexamethasone (VBAMDex) therapy for multiple myeloma. Early results of a multicenter trial. The German Myeloma Treatment Group. Onkologie. 1990;13(1):43-4.

107. Peest D, Schmoll HJ, Schedel I, Deicher H, Boll J, Essers U, et al. Current results of a multicenter trial in multiple myeloma. Onkologie. 1986;9(3):168-9.

108. Porter CA, Rifkin RM. Clinical benefits and economic analysis of pegylated liposomal doxorubicin/vincristine/dexamethasone versus doxorubicin/vincristine/dexamethasone in patients with newly diagnosed multiple myeloma. Clin Lymphoma Myeloma. 2007;7(Suppl 4):S150-5.

109. Rajkumar SV, Blood E, Vesole D, Fonseca R, Greipp PR, Eastern Cooperative Oncology Group. Phase III clinical trial of thalidomide plus dexamethasone compared with dexamethasone alone in newly diagnosed multiple myeloma: a clinical trial coordinated by the Eastern Cooperative Oncology Group. J Clin Oncol. 2006;24(3):431-6.

110. Rajkumar SV, Hussein M, Catalano J, Jedrzejcak W, Sirkovich $\mathrm{S}$, Olesnyckyj $\mathrm{M}$, et al. A multicenter, randomized, doubleblind, placebo-controlled trial of thalidomide plus dexamethasone versus dexamethasone alone as initial therapy for newly diagnosed multiple myeloma. J Clin Oncol. 2006;24(18S Pt 1):426.

111. Rajkumar SV, Rosiñol L, Hussein M, Catalano J, Jedrzejczak W, Lucy L, et al. Multicenter, randomized, double-blind, placebocontrolled study of thalidomide plus dexamethasone compared with dexamethasone as initial therapy for newly diagnosed multiple myeloma. J Clin Oncol. 2008;26(13):2171-7.

112. Report on the second myelomatosis trial after five years of follow-up. Medical Research Council's Working Party on Leukaemia in Adults. Br J Cancer. 1980;42(6):813-22.

113. Riccardi A, Mora O, Brugnatelli S, Tinelli C, Spanedda R, De Paoli $A$, et al. Relevance of age on survival of 341 patients with multiple myeloma treated with conventional chemotherapy: updated results of the MM87 prospective randomized protocol. Cooperative Group of Study and Treatment of Multiple Myeloma. Br J Cancer. 1998;77(3):485-91.

114. Riccardi A, Mora O, Tinelli C, Porta C, Danova M, Brugnatelli $\mathrm{S}$, et al. Response to first-line chemotherapy and longterm survival in patients with multiple myeloma: results of the MM87 prospective randomised protocol. Eur J Cancer. 2003;39(1):31-7.

115. Riccardi A, Mora O, Tinelli C, Valentini D, Brugnatelli S, Spanedda $\mathrm{R}$, et al. Long-term survival of stage I multiple myeloma given chemotherapy just after diagnosis or at progression of the disease: a multicentre randomized study. Cooperative Group of Study and Treatment of Multiple Myeloma. Br J Cancer. 2000;82(7):1254-60.
116. Richardson $P$, Sonneveld $P$, Schuster $M$, Irwin D, Stadtmauer $E$, Facon $\mathrm{T}$, et al. Bortezomib demonstrates superior survival compared with high-dose dexamethasone and higher response rates after extended follow-up in the APEX trial in relapsed multiple myeloma. Haematologica. 2006; 91(Suppl 1):224.

117. Richardson PG, Sonneveld P, Schuster M, Irwin D, Stadtmauer $E$, Facon $T$, et al. Extended follow-up of a phase 3 trial in relapsed multiple myeloma: final time-to-event results of the APEX trial. Blood. 2007;110(10):3557-60.

118. Richardson PG, Sonneveld P, Schuster MW, Irwin D, Stadtmauer EA, Facon $\mathrm{T}$, et al. Bortezomib or high-dose dexamethasone for relapsed multiple myeloma. N Engl J Med. 2005;352(24):2487-98

119. Rifkin RM, Gregory SA, Mohrbacher A, Hussein MA. Pegylated liposomal doxorubicin, vincristine, and dexamethasone provide significant reduction in toxicity compared with doxorubicin, vincristine, and dexamethasone in patients with newly diagnosed multiple myeloma: a Phase III multicenter randomized trial. Cancer. 2006;106(4):848-58.

120. Rajkumar SV, Jacobus S, Callander N, Fonseca R, Vesole D, Williams $\mathrm{M}$, et al. Phase III trial of lenalidomide plus high-dose dexamethasone versus lenalidomide plus low-dose dexamethasone in newly diagnosed multiple myeloma (E4A03): a trial coordinated by the Eastern Cooperative Oncology Group. J Clin Oncol. 2007;25(18S):8025

121. San Miguel JF, Schlag R, Khuageva NK, Dimopoulos MA, Shpilberg O, Kropff M, et al; VISTA Trial Investigators. Bortezomib plus melphalan and prednisone for initial treatment of multiple myeloma. N Engl J Med. 2008;359(9):906-17.

122. Shimizu K, Kamiya O, Hamajima N, Mizuno H, Kobayashi M, Hirabayashi $\mathrm{N}$, et al. Multi-drug combination therapy with vincristine-melphalan-cyclophosphamide-prednisolone was more effective than cyclophosphamide-prednisolone in stage III myeloma. The Nagoya Myeloma Cooperative Study Group. Jpn J Cancer Res. 1990;81(12):1320-7.

123. Spencer A, Roberts A, Kennedy N, Ravera C, Cremers S, Bilic $S$, et al. Renal safety of zoledronic acid with thalidomide in patients with myeloma: a pharmacokinetic and safety sub-study. BMC Clin Pharmacol. 2008;8:2.

124. Takenaka T, Itoh K, Suzuki T, Utsunomiya A, Matsuda S, Chou T, et al; Lymphoma Study Group of the Japan Clinical Oncology Group. Phase III study of ranimustine, cyclophosphamide, vincristine, melphalan, and prednisolone (MCNU-COP/ MP) versus modified COP/MP in multiple myeloma: a Japan clinical oncology group study, JCOG 9301. Int J Hematol. 2004;79(2):165-73

125. Umeda M, Katoh M, Niitsu N, Takata M, Katoh M, Shikoshi K. [VCAP chemotherapy combined with interferon-alpha (HLBI) for elderly multiple myeloma]. Nippon Ronen Igakkai zasshi. Jap J Geriatrics. 1994;31(12):969-74.

126. Waage A, Gimsing P, Juliusson G, Turesson I, Fayers P. Melphalan-prednisone-thalidomide to newly diagnosed patients with multiple myeloma: a placebo controlled randomised phase 3 trial. Blood. 2007;110(11):32a

127. Zervas K, Mihou D, Katodritou E, Pouli A, Mitsouli CH, Anagnostopoulos A, et al; Greek Myeloma Study Group. VAD-doxil versus VAD-doxil plus thalidomide as initial treatment for multiple myeloma: results of a multicenter randomized trial of the Greek Myeloma Study Group. Ann Oncol. 2007;18(8):1369-75.

128. Zervas K, Pouli A, Gregoraki B, Anagnostopoulos N, Dimopoulos MA, Bourantas K, et al. Comparison of vincristine, carmus- 
tine, melphalan, cyclophosphamide, prednisone (VBMCP) and interferon-alpha with melphalan and prednisone (MP) and interferon-alpha (IFN-alpha) in patients with good-prognosis multiple myeloma: a prospective randomized study. Greek Myeloma Study Group. Eur J Haematol. 2001;66(1):18-23.

129. Zonder JA, Crowley J, Hussein MA, Bolejack V, Moore DF, Whittenberger $\mathrm{BF}$, et al. Superiority of lenalidomide (Len) plus high-dose dexamethasone (HD) compared to HD alone as treatment of newly-diagnosed multiple myeloma (NDMM): results of the randomized, double-blinded, placebo-controlled SWOG trial S0232. Blood. 2007;110(11):32a.

130. Durie BGM, Salmon SE. A clinical staging system for multiple myeloma. Correlation of measured myeloma cell mass with presenting clinical features, response to treatment, and survival. Cancer. 1975;36(3):842-54.

131. Greipp PR, San Miguel J, Durie BG, Crowley JJ, Barlogie B, Bladé J, et al. International staging system for multiple myeloma. J Clin Oncol. 2005;23(15):3412-20.

132. Kapoor P, Snozek CL, Colby C, Larson DR, Katzmann JA, Rajkumar SV, et al. Clinical impact of discordance in serum albumin measurements on myeloma international staging system. J Clin Oncol. 2008;26(24):4051-2.

133. Nowakowski GS, Witzig TE, Dingli D, Tracz MJ, Gertz MA, Lacy MQ, et al. Circulating plasma cells detected by flow cytometry as a predictor of survival in 302 patients with newly diagnosed multiple myeloma. Blood. 2005;106(7):2276-9.

134. Hicks LK, Haynes AE, Reece DE, Walker IR, Herst JA, Meyer RM, et al.; Hematology Disease Site Group of the Cancer Care Ontario Program in Evidence-based Care. A meta-analysis and systematic review of thalidomide for patients with previously untreated multiple myeloma. Cancer Treat Rev. 2008;34(5):442-52

135. Barlogie B, Tricot G, Anaissie E, Shaughnessy J, Rasmussen $E$, van Rhee $F$, et al. Thalidomide and hematopoieticcell transplantation for multiple myeloma. N Eng J Med. 2006:354(10):1021-30
136. Mateos M-V, Oriol A, Martínez J, et al. Bortezomib (Velcade)melphalan-prednisone (VMP) versus Velcad-thalidomideprednisone (VTP) in elderly untreated multiple myeloma patients: which is the best partner for Velcade: an ankylating or an immunomodulator agent? Program and abstracts of the 50th American Society of Hematology Annual Meeting and Exposition; December 6-9, 2008; San Francisco, California. Abstract 651.

137. Palumbo $A$, Bringhen $S$, Rossi $D$, Magarotto $V$, Raimondo $F$, Ria $R$, et al. A prospective, randomized, phase III study of bortezomib, melphalan, prednisone, and thalidomide (VMPT) versus bortezomib, melphalan and prednisone (VMP) in elderly newly diagnosed myeloma patients. Program and abstracts of the 50th American Society of Hematology Annual Meeting and Exposition; December 6-9, 2008; San Francisco, California. Abstract 652

138. Lacy MQ, Gertz MA, Dispenzieri A, Hayman SR, Geyer S, Kabat $B$, et al. Long-term results of response to therapy, time to progression, and survival with lenalidomide plus dexamethasone in newly diagnosed myeloma. Mayo Clin Proc. 2007;82(10):1179-84.

139. Rajkumar SV, Jacobus S, Callander N, Fonseca D, Vesole $M$, Williams $R$, et al. Randomized trial of lenalidomide plus high-dose dexamethasone versus lenalidomide plus lowdose dexamethasone in newly diagnosed myeloma (E4A03), a trial coordinated by the Eastern Cooperative Oncology Group: analysis of response, survival, and outcome with primary therapy and with stem cell transplantation. Program and abstracts of the 44th American Society of Clinical Oncology Annual Meeting; May 30 - June 3, 2008; Chicago, Illinois. Abstract 8504.

140. Palumbo A, Sezer O, Kyle R, Miguel JS, Orlowski RZ, Moreau $\mathrm{P}$, et al; on behalf of the IMGW. International Myeloma Working Group guidelines for the management of multiple myeloma patients ineligible for standard high-dose chemotherapy with autologous stem cell transplantation. Leukemia. 2009;23(10):1716-30. 